\title{
Sultan II. İzzeddin Keykâvus Döneminde Sarı Saltuk'un Balkanlara Geçişine Dâir Mütâlaalar
}

\section{The Examinations on Passage of Sari Saltuk to Balkans During the Reign of Sulțan 'Izz Al-Dīn Kaykāwus II}

\author{
PInar Kaya Tan' ${ }^{1}$
}

'Sorumlu yazar/Corresponding author: Pınar Kaya Tan (Dr. Öğr. Üyesi), Kırklareli Üniversitesi Fen-Edebiyat Fakültesi, Tarih Bölümü, Kırklareli, Türkiye. E-Posta: pinarkaya@klu.edu.tr ORCID: 0000-0002-7025-399X

Başvuru/Submitted: 03.01.2021 Revizyon Talebi/Revision Requested: 23.03.2021

Son Revizyon/Last Revision Received: 13.11.2021

Kabul/Accepted: 15.11.2021

Atıf/Citation: Kaya Tan, Pinar, "Sultan II. İzzeddin Keykâvus Döneminde Sarı Saltuk'un Balkanlara Geçişine Dâir Mütâlaalar", Güneydoğu Avrupa Araştırmaları Dergisi, 37 (2021), s. 99-123 https://doi.org/10.26650/gaad.094237

\section{öz}

Sultan II. Glyâseddin Keyhüsrev'in büyük oğlu olan II. İzzeddin Keykâvus dönemi (1256-1249 müstakil, 1249-1262 müşterek saltanat) Türkiye Selçuklu Devleti tarihi açısından son derece kritik hâdiselerin yaşandığı bir devir olmuştur. II. Gıyâseddin Keyhüsrev döneminde yapılan Kösedağ Savaşı (641/1243) ile Anadolu'da başlayan Moğolların tahakkümü giderek artmış ve II. İzzeddin Keykâvus döneminde bu baskılar ağır bir şekilde hissedilir olmuştu. Ayrıca siyasî, sosyal, idarî dengelerin ve devlet yönetiminde etkili olan şahsiyetlerin suhuletle değişebildiği de görülmüştür. Moğolları Anadolu'dan çıkarmak için askerî ve diplomatik mücâdelelerde bulunmuşsa da muktedir bir idâre sergileyemeyen Sultan II. İzzeddin Keykâvus nihayetinde tahtını terk etmek ve Bizans İmparatoru VIII. Mikhail Palailogos'a (1261-1282) sığınmak zorunda kalmıştır. Bu dönemde sultana bağlıık arz eden yakın adamları ve emîrleri ile liderlerinin Sarı Saltuk (ö. 697/1297-1298) olduğu düşünülen çok sayıda Türkmen'in, günümüzde Bulgaristan ve Romanya sınırları içinde yer alan Dobruca bölgesine yerleştirildikleri çeşitli kaynaklarda zikredilmektedir. Bu çalışmada özellikle Sarı Saltuk ve Selçuklu Sultanı II. İzzeddin Keykâvus arasındaki münâsebetler ve Türkmenlerin göç hâdisesi üzerine önce tarihî kaynaklar ardından da ikincil literatürde yer alan mâlûmat bir araya getirilmiş ve bu husustaki mevcut görüşler irdelenmiştir.

Anahtar Kelimeler: II. İzzeddin Keykâvus, Sarı Saltuk, Türkmenler, Dobruca, VIII. Mikhail Palailogos

\begin{abstract}
The reign of 'Izz al-Dīn Kaykāwus II (1246-1249 detached, 1249-1262 joint reign) elder son of Sulțan Ghiyāth al-Dīn Kaykhusraw II, is a period of highly critical developments with respect to the history of Turkey Saldjūk State. With the Köse Dagh Battle (641/1243) that took place during the reign of Ghiyāth al-Dīn Kaykhusraw II, Mongol dominance starting in Anatolia has increased and were heavily felt during the reign of 'Izz al-Dīn Kaykāwus II. Furthermore, it is seen that political, social and administrative balance as well as persons
\end{abstract}


with influence in the government could easily change. Despite engaging in military and diplomatic manoeuvers to expelling Mongols from Anatolia, Sulțan 'Izz al-Dīn Kaykāwus II failed to exhibit competent management and eventually had to abandon the throne and sought refuge under Byzantine Emperor Mikhail VIII Palailogos (1261-1282). Various sources mention that people and āmirrs loyal to the sultan and numerous Turkmen who are thought to be led by Sari Saltuk (d. 697/1297-1298) have been settled in Dobrudja region, which is in the borders of modern Bulgaria and Romania. This study assembles information initially in historic resources and secondary literature on the relations of Sari Saltuk and Saldjūḳ Sulțan 'Izz al-Dīn Kaykāwus II and the migration of Turkmen and analyses the present views on this subject.

Keywords: 'Izz al-Dīn Kaykāwus II, Sari Saltuk, Turkmen, Dobrudja, Mikhail VIII Palailogos

\section{EXTENDED ABSTRACT}

The reign of Turkey Saldjūḳ State Sulțan 'Izz al-Dīn Kaykāwus II (1246-1249 detached, 1249-1262 joint reign) has been a period of important events for Turkish history and the history of the Turkey Saldjūk State. During that difficult period, the invasion of Mongols had increased in Anatolia, three Saldjūk rulers for the first time in Turkey's history ascended the throne at the same time and even the country was divided into two by the Mongols. The Sulțan 'Izz al-Dīn sent a message from Antalya to the Mamlūk Sulțan Baibars (1260-1277) when he heard that the Mongol commanders came to Aksaray with a crowded soldiers and Rukn al-Dīn Kilicarslan IV and his vizier Parwāna Mu'īn al-Dīn were with them, asking Baibars for help. Yet, when he heard that was not possible, 'Izz al-Dīn Kaykāwus II decided to take refuge in Byzantium. The Sulțan boarded a ship with his family, mother, uncles, some amirrs and close statesmen and went to Istanbul (1262). Emperor Mikhail VIII Palaiologos welcomed Kaykāwus friendly. Before long, at the request of the Sulțan 'Izz al-Dīn Kaykāwus II with the permission of the Emperor Mikhail Palaiologos under the spiritual leadership of Sari Saltuk, thousands of Turkmen groups were placed in Rūmeli in Dobrudja. The warriors of those nomadic groups participated in some victorious wars on the side of the emperor, in particular, one may think, during the re-conquest of Dobrudja on behalf of Mikhail Palaiologos VIII. On the other hand, Sulțan 'Izz al-Dīn was imprisoned due to a conspiracy against the Byzantine emperor. Before long the Khan of the Golden Horde State and the Sultan of the Mamluks rescued him and Sulțan 'Izz al-Dīn Kaykāwus II immigrated to Crimea.

On the other hand, Sari Saltuk, a historical person, played an important role in Turkification and Islamization of a wide geography in the $13^{\text {th }}$ century. We have limited information about Sari Saltuk's historical life as his life is mixed with legends because very few sources refer to the historical Sari Saltuk. In addition, various research about Sari Saltuk's life and activities have been presented in primary and secondary sources, and at national and international symposiums. In this work, especially the relations between Sari Saltuk and Saldjūk Sulțan 'Izz al-Dīn Kaykāwus II as well as the migration of Turkmens in Dobrudja first historical sources and then secondary literature were brought together, and current opinions on this issue were examined. The narrations of primary sources, Ottoman historians, orientalists, 
Romanian, Bulgarian and Turk historians were given in the chronological order. In contrast with the scarcity of historical sources and reliable data concerning Sari Saltuk, there is a vast body of oral and written narratives on his spiritual life, his endless wars, his fantastic adventures and miracles. Saldjūḳid sources in Persian do not even mention that a group of Turkmen together with Sulțan 'Izz al-Dīn Kaykāwus II who had taken refuge with the Byzantines in 1262 migrated to the Dobrudja, and certainly not that migration was headed by a person known as Sari Saltuk. However, contemporary Byzantine sources confirm the migration of Turkmen. Kamāl al-Dīn Muḥammad al-Sarrāj, Ibn Bațtuța, Evliya Chelebi also give information about the presence of Sari Saltuḳ and accompanying Turkmen in Rūmeli and Dobrudja. Orientalists such as J. von Hammer, J. Deny, P. Wittek and A. Decei about the Turkmen settlement in Dobrudja, mostly benefited Ottoman historians like Yazicioghlu's and Loqmān's account. From the important and comprehensive of these sources, Saltuknāme is a large compilation that is the epic romance on the Islamic conquests of Sari Saltuk. Abu al-Khair Rūmī travelled around Anatolia and Balkans for many years compiling the legends of Sari Saltuk and creating the Saltuknāme. In this work, the information in these sources has been tried to be compared with historical facts. The archaeological findings, tombs, old settlements and especially the legends and oral histories that have been studied in today's research show how the Turkmen led by Sari Saltuk left permanent marks in the Balkans. 


\section{Giriş}

Sarı Saltuk, XIII. yüzyılda Türk kültürünün ve Türk tarihinin en önde gelen efsanevî şahsiyetlerinden ve Anadolu ve Balkanların Müslümanlaşmasında derin etkiler bırakan alperenlerden biri olarak karşımıza çıkmaktadır. Ancak Sarı Saltuk'un gerçek hayatı ile adıyla özdeşleşen menkıbeleri iç içe geçmiş; bu durum da onun biyografisini ortaya koymamızı, tarihî kişiliği hakkında bilgi sahibi olmamızı sınırlandırmıştır. Sarı Saltuk'un berâberindeki Türkmenler ile birlikte Konstantinopolis'e' (İstanbul) Bizans İmparatoru'na sığınmış olan Türkiye Selçuklu Sultanı II. İzzeddin Keykâvus'un gayretleri neticesinde Rumeli'ye geçtiği hususunda kaynaklarda, araştırma eserlerde ve seyahatnâmelerde mâlûmat bulunmaktadır. Bununla berâber kaynaklarda daha ziyade Sarı Saltuk'un İslâmiyeti yayma hususundaki teşebbüsleri, dinî liderliği üzerinde durulduğu için onun ve berâberindeki Türkmenlerin Rumeli coğrafyasında yer alan Dobruca ve kuzeyindeki bölgelere geçişleri hakkındaki bilgiler son derece kısıtlıdır. Bu çalışma ise kalabalık kafilelerin II. İzzeddin Keykâvus ve maiyetindekilerin çabaları neticesinde Bizans topraklarına gelişi hakkında gerek tarihî kaynaklarda gerekse Türk ve Batıı araştırmacıların eserlerinde verilen bilgilerin mukayese edilmesine ve bir araya getirilmesine katkı sağlamak amacıyla hazırlanmıştır. Sarı Saltuk ve berâberindeki Türkmenlerin Dobruca'ya geçtikten sonraki durumları, ardından yine Sultan II. İzzeddin Keykâvus'u takip ederek Deşt-i Kıpçak'a gidişleri, sultanın vefatının akabinde büyük kısmının Dobruca'ya geri dönmeleri ve burada sürdürmüş oldukları irşad faâliyetleri ise araştırmanın kapsamı dışındadır. Literatürde bu yer değiştirme hâdisesi ile ilgili olarak rastlamış olduğumuz mâlûmatı zikretmeden önce devrin siyasî tarihi, olayları ve sosyal yapısı hakkında bilgi vermek faydalı olacaktır.

Bizans İmparatorluğu'nun mukavemetinin kırılmasıyla birlikte Türkler Anadolu'da fethettikleri bölgelerde kalıı bir şekilde yerleşmeye başlamışlardı. Bilhassa tarım ve hayvancılığa son derece elverişli olan topraklara yüzyıllar boyu sürecek olan Türkmen göçleri ve Türkiye Selçuklu Devleti'nin (467-708/1075-1308) de kurulmasıyla berâber, Anadolu'nun fethi ve Türkleşmesi süreci hız kazanmıştı. Türkiye Selçuklu sultanları daha kuruluş yıllarından itibaren Bizans İmparatorluğu'na ve akabinde Haçıllara karşı yerleşmiş oldukları toprakları muhâfazaya çalışmışlar; devletin kurucusu Anadolu fâtihi Süleyman Şah'ın (467-479/10751086) sağlamaya çalıştığı siyasî birliği devam ettirmeye büyük özen göstermişlerdir. Ancak Moğollar karşısında kaybedilen Kösedağ Savaşı (Muharrem 641/Temmuz 1243) neticesinde Anadolu, doğudan gelen düşmanın tahakkümüne girmiş ve giderek ağırlaşan şartların da etkisiyle devlet bir türlü kendini toparlayamaz olmuştu. ${ }^{2}$

Bu sıkıntıı devirde Sultan II. Gıyâseddin Keyhüsrev'in vefatının ardından geride kalan üç oğlundan annesi Konyalı bir Hristiyanın kızı Berdûliye Hatun olan II. İzzeddin Keykâvus, devlet adamlarının da yardımlarıyla tahta çıkartılmıştır. Bu esnâda Moğol tahtına Güyük Hân'ın

1 Makalede Bizans İmparatorluğu'nun başkenti İstanbul olarak zikredilecektir.

2 Mehmet Şeker, "Anadolu'nun Türk Vatanı Haline Gelmesi", Türkler, Ankara 2002, C. VI, 269-282; Faruk Sümer, "Selçuklular III. Anadolu Selçukluları (1075-1038)", Türkiye Diyanet Vakfı İlâm Ansiklopedisi (DiA), XXXVI, 380-384. 
(644-645/1246-1248) çıkması sebebiyle Sultan II. İzzeddin Keykâvus, Moğolistan'a dâvet edildi, fakat Konya'yı terk etmek istemeyen sultanın yerine kardeşi IV. Kılıç Arslan'ın Güyük Hân'ın cülûs merasimine gitmesi kararlaştıııldı. IV. Rükneddin Kılıç Arslan'ın Hân'dan yarlık alarak geri dönmesi ve sultanlığın kendisine âit olduğunu ileri sürmesi üzerine, ülke içinde bir siyasî krizin yaşanmasını engellemek isteyen saltanat nâibi Celâleddin Karatay (ö. 652/1254) II. İzzeddin Keykâvus ve diğer iki kardeşinin aynı anda tahta oturmasını, hutbe ve sikkelerde doğum sırasına göre isimlerinin kullanılmasını teklif etti. Böylelikle emîrlerin ortak kararı ile Türkiye Selçuklu Devleti tarihinde ilk defa üç hükümdar aynı zamanda tahta çıkmış oldu (Rebîülevvel 647/Haziran-Temmuz 1249). ${ }^{3}$

Ancak ülkedeki iç sükûnet bir türlü sağlanamıyordu. Celâleddin Karatay'ın ve çok geçmeden de tahta çıkartılan kardeşlerden II. Alâeddin Keykubad'ın (ö. 652/1254) vefatlarının ardından huzursuzluklar giderek artmaya başladı. II. İzzeddin Keykâvus içkiye ve eğlenceye fazlaca düşkün olduğundan devlet ileri gelenleri IV. Kı ıç Arslan'ı desteklemeye başladılar. Hatta onu Kayseri'de tahta çıkardılar. İki kardeş arasında savaş kaçınılmaz hâle gelince mücâdeleden galibiyetle çıkan taraf II. İzzeddin Keykâvus oldu. IV. Rükneddin Kılıç Arslan vuku bulan gelişmelerin ardından önce Amasya'ya sonrasında da Borgulu (Uluborlu) Kalesi'ne gönderilerek hapsedildi. ${ }^{4}$

II. İzzeddin Keykâvus'ın müstakil olarak saltanatta olduğu dönemde ise Moğol büyük hânı Mengü 649-657/1251-1259) İran ve Batı ülkelerinin idâresini kardeşi Hülâgû'ya (654663/1256-1265) bıraktı. İlhanlı Devleti'nin de kurucusu olan Hülâgû, Azerbaycan'da bulunan Mugan'ı kışlak olarak kullanmaya karar verdi. Kente evvelce yerleşmiş olan Moğol ordusu kumandanı Baycu Noyan ise bir Moğol şehzadesinin isteğine karşı koyacak gücü kendinde bulamayarak oradan ayrımak zorunda kaldı. Otağını toplayarak Anadolu'ya doğru hareket etti. Baycu Noyan, II. İzzeddin Keykâvus'a bir elçi göndererek Anadolu'da kendisine yaylak ve kışlak talep ettiyse de emîrlerini dinlemeyen ve ordusuna güvenen sultan, savaşmayı tercih edip nihâyetinde ağır bir yenilgiye uğradı (654/1256). ${ }^{5}$ II. İzzeddin Keykâvus muhârebenin ertesi günü de Antalya'ya firar etti. Moğollara vermek üzere para ve altın toplayan Konya halkı, bir yandan II. İzzeddin Keykâvus ve askerlerinin şehri terk etmiş olmalarından dolayı paniğe

3 İbn Bîbî, el-Evâmirü'l- 'Alấiyye fi'l-umûri'l- 'Alấiyye, Türkçe trc. Mürsel Öztürk, Ankara 1996, II, 121-122; İnü'lİbrî, Abû́l-Farac Tarihi, Türkçe trc. Ömer Rıza Doğrul, Ankara 1950, II, 545-549; a. mlf., Târîhu muhtasari'd-düvel, Beyrut 1308/1890, s. 449-451; Kerîmüddin Mahmûd Aksarâyî, Müsâmeretü'l-Ahbâr, Türkçe trc. Mürsel Öztürk, Ankara 2000, s. 27-28; Osman Turan, Selçuklular Zamanında Türkiye, İstanbul 1971, s. 465-469; Claude Cahen, La Turquie pré-ottomane, Türkçe trc. Erol Üyepazarcı, Osmanlılardan Önce Anadolu, İstanbul 2000, s. 243; Abdülkerim Özaydın, "Anadolu Selçukluları", Siyasî-Dinî-Kültürel-Sosyal İslâm Tarihi, İstanbul 1994, VIII, 175177; Mehmet Suat Bal, "Türkiye Selçuklu Devleti Tarihinde Bir Dönüm Noktası; II. İzzeddin Keykavus Dönemi”, Tarih Araştırmaları Dergisi (TAD), C. XXIV, Sayı: 38, (2005), s. 241; Faruk Sümer, “Keykâvus II”, DIA, XXV, 355.

4 Aksarâyî, a. g. e., s. 30; Târih-i Âl-i Selçuk (Anonim Selçuknâme), Türkçe trc. Halil ỉbrahim Gök-Fahrettin Coşguner, Ankara 2014, s. 45; Turan, a. g. e., s. 472-475; Kansu Ekici, Anadolu Selçuklu Devletinde Üç Kardeş Devri (1246-1266), Süleyman Demirel Üniversitesi Sosyal Bilimler Enstitüsü, Yayımlanmamış Yüksek Lisans Tezi, Isparta 2005, s. 30-34.

5 Turan, a. g. e., s. 479-480; Ekici, a. g. e., s. 37. 
kapılarak kentin kapılarını Moğollara kapatmışlar, diğer yandan ise canlarıı kurtarmak umuduyla aralarında topladıkları para ve emtiayı Baycu Noyan'a göndermişlerdi. Böylelikle şehir yıkımdan; Konya halkı da büyük bir katliamdan kurtulmuş oldu. ${ }^{6}$

II. İzzeddin Keykâvus bir süre Antalya'da kaldıktan sonra buradan İznik İmparatoru II. Laskaris'in (1254-1258) yanına geçti. Öte taraftan Selçuklu tahtına ise Baycu Noyan'ın da desteğiyle yeniden IV. Kılıç Arslan çıktı (16 Safer 655/5 Mart 1257). Ancak İznik Imparatoru'na sığınmak zorunda kalan II. İzzeddin Keykâvus, meydana gelen hâdiseleri Hülâgû Han'a şikâyet mahiyetinde bildirdi. Baycu Noyan'ın ve kardeşinin birlikte hareket ederek kendisini saltanatından ve atalarının mirasından mahrum etmeye gayret sarf ettiklerini iletti. Gelişmeleri öğrenen Hülâgû Han, müdâhalede bulunmayı tercih ederek memleketin iki kardeş arasında taksim edileceğini bildirdi. 'T Gerçekten de çok geçmeden Illhanlı hükümdarı Hülâgû'nun Bağdat üzerine yürüyeceği sefere destek vermesi için Baycu'yu çağırmasını fırsat bilen II. İzzeddin Keykâvus, başkent Konya'ya gelerek yeniden tahta oturdu. Öte taraftan IV. Rükneddin Kılıç Arslan Kayseri taraflarına doğru çekilse de mücâdeleyi bırakma niyetinde değildi. Nihâyet II. İzzeddin Keykâvus ve IV. Rükneddin Kılıç Arslan birlikte Hülâgû Han'ın yanına gittiler. İlk önce huzura II. İzzeddin Keykâvus çıkmış ve kendisine büyük teveccüh gösterilmiştir. ${ }^{8}$ Hülâgû Han aynı şekilde IV. Kılıç Arslan'a da oldukça iyi davranmış ve Anadolu'yu iki kardeş arasında paylaştırmıştır. Buna göre II. İzzeddin Keykâvus, başkenti Konya olacak şekilde Kayseri hududundan Antalya sahillerine kadar uzanan topraklara hükmedecekti. IV. Rükneddin Kılıç Arslan ise Sivas'tan Sinop ve Samsun sahillerine kadar olan Dânişmendli vilâyeti civarındaki topraklarda merkezi Tokat olmak üzere hükmedecekti.

\section{Sultan II. İzzeddin Keykâvus'un İstanbul'a Geçişi ve Burada Yürütmüş Olduğu Faâliyetleri}

Selçuklu ülkesinin II. İzzeddin Keykâvus ve IV. Kılıç Arslan arasında ikiye bölünmesinin ardından, II. İzzeddin Keykâvus, dayılarıyla birlikte Antalya'ya geçerek eğlenceye dalmış, devlet işlerini yine boşlamıştı. ${ }^{10}$ Ancak yaşanan gelişmelere rağmen yeni dostluklar edinmek üzere temaslarda bulunmayı da ihmâl etmiyordu. Memlük Sultanı Baybars'la (658-676/1260-1277) ve onun müttefiki olan Altın Orda adlı Moğol-Türk Hakanlığıla iyi ilişkiler kurarak müttefik olmaya çalışıyordu. Geçmiş yıllardan beri dostâne münâsebetler sürdürdüğü Bizans İmparatoru VIII. Mikhail Palaiologos'la (1259-1282) da diplomatik temaslar kuruyordu. Çok geçmeden bu ittifakların Moğollar tarafından açığa çıkması üzerine kendisini güç bir durum içerisinde

6 İbn Bîbî, a. g. e., II, 13; ỉbnü'l-Ibrî, Abû́l-Farac Tarihi, II, 562; Turan, a. g. e., s. 481-482; Mehmet Suat Bal, II. İzeddin Keykâvus Dönemi (1246-1262), Ankara Üniversitesi Sosyal Bilimler Enstitüsü, Yayımlanmamış Doktora Tezi, Ankara 2004, s. 100-102; Ekici, a. g. e., s. 39-40.

7 ỉbnü'l-ibrî, Abû'l-Farac Tarihi, II, 563; Bal, a. g. m., TAD, C. XXIV, Sayı: 38, s. 245;

8 İbn Bîbî, a. g. e., II, 155-156; Aksarâyî, a. g. e., s. 45.

9 Aksarâyî, a. g. e., s. 46; İbnü'l-Ibrî, Târîhu muhtasari'd-düvel, s. 539; Turan, a. g. e., 491; Ekici, a. g. e., s. 48-49; Bal, a. g. m., TAD, C. XXIV, Sayl: 38, s. 245.

10 Turan, a. g. e., s. 493; Sümer, “Keykâvus II”, DiA, XXV, s. 355. 
bulan Keykâvus, IV. Rükneddin Kılı̧ Arslan ve onun destekçisi Moğollar tarafından sıkıştııııp güç duruma düşünce de gemi yoluyla Antalya'dan İstanbul'a Bizans İmparatorluğu'na kaçmak zorunda kaldı (660/1262). ${ }^{11}$

Sultanın maiyetiyle birlikte yanına gitmiş olduğu VIII. Mikhail Palaiologos, evvelce Lâtinlerin baskısı altında bulunduğu sırada II. İzzeddin Keykâvus'a sığınmış ve Selçuklu sultanı tarafından kendisine büyük hürmet gösterilmişti. Ülkesine geri döndükten sonra ise İznik'i ve İstanbul tahtını elde etmekte muvaffak olmuştu. ${ }^{12}$

II. İzzeddin Keykâvus İstanbul'a sığınırken hanımlarını, çocuklarını, dinî vecibelerine son derece bağlı olan Hıristiyan annesini, kız kardeşini de berâberinde götürmüştü. ${ }^{13}$ Ayrıca Hıristiyan dayıları Kir Hâye ve Kir Kedîd, bazı emîrleri ve maiyeti de yanında bulunuyordu. ${ }^{14}$ Sultana "uygun zaman geldiğinde geri dönüp halkı üzerindeki hâkimiyetini yeniden tesis edebileceğinin güvencesi” verildi. Netice olarak sultan, imparatorun yanında hüsn-ü kabul gördü, emrine onu koruması için birlik verildi. Hatta II. İzzeddin Keykâvus hâkimiyet alâmetlerinden sayılan kırmızı çizmeler giyiyor ve istediği gibi yaşamasına müsâade ediliyordu. II. İzzeddin Keykâvus kendisine verilen bu imkânlardan en iyi şekilde kazanç sağlamaya çalışıyordu. Ayrıca VIII. Mikhail Palaiologos II. İzzeddin Keykâvus'a tahtını yeniden elde etmesi için askerî destekte bulunacağına dâir vaatlerde de bulunuyordu..$^{15}$

Çok geçmeden Bizans İmparatoru, II. İzzeddin'in maiyetindekileri, özellikle kadınları ve çocukları, muhâfaza edilmeleri için İznik'e yolladı. VIII. Mikhail Palaiologos, sultanı da kendisiyle berâber Balkanlara sefere götürdü. Ayrıca Il. İzzeddin Keykâvus'a himâyesinde bulunanları güvenlikleri için İznik'e gönderdiğini söyledi. İmparator, II. İzzeddin Keykâvus'u kontrolü altında tutabilmeye çalışıyordu. ${ }^{16}$

Ardından II. İzzeddin Keykâvus, Bizans İmparatoru'nun himâyesi altında günlerini geçirmeye devam etti. Bu esnada Doğu'da Altın Orda Hakanlığı́nın hükümdarlığına geçen Berke Han'ın (654-665/1256-1266) İslâmiyeti kabulü ve Memlük Sultanı Baybars'ın söz konusu ittifakı sayesinde Altın Orda ve İlhanlı devletlerinin birbirleriyle rekabeti giderek artıyordu. II. İzzeddin Keykâvus daha İstanbul'a gitmeden önce temaslar kurduğu bu cephenin bir mensubu olarak siyasî gelişmelerden istifâde etmeye çalışıyordu. ${ }^{17}$ Bizans İmparatoru ise Hülâgû

11 İbn Bîbî, a. g. e., II, 159-160; Turan, a. g. e., s. 496-497; Sümer, “Keykâvus II”, DiA, XXV, 356.

12 Georgios Pachymeres, Georges Pachymérès Relations Historiques, ed. Albert Failler, Paris 1984-1999, I, 148149; a. mlf., Bizanslı Gözüyle Türkler, Türkçe trc. İlcan Bihter Barlas, İstanbul 2009, s. 31-32; Tamara Talbot Rice, The Seljuks in Asia Minor, London 1961, s. 76; Georg Ostrogorsky, Bizans Devleti Tarihi, Türkçe trc. Fikret Işıltan, Ankara 2011, s. 411-412.

13 ỉbn Bîbî, a. g. e., II, 159-160; Pachymeres, a. g. e., I, 182-185; Türkçe trc. İlcan Bihter Barlas, s. 35.

14 Turan, a. g. e., s. 497. Sultan II. İzzeddin Keykâvus'un bu süreçte yanında bulunan hânedan üyeleri hakkında bkz. Rustam Shukurov, The Byzantine Turks 1204-1461, Leiden 2016, s. 105-131.

15 İbn Bîbî, a. g. e., II, 160-161; Pachymeres, a. g. e., I, 184-185; Türkçe trc. Illcan Bihter Barlas, s. 36; Turan, a. g. e., s. 497; Erdoğan Merçil, "Bizans'ta Selçuklu Hanedan Mensupları”, XI. Türk Tarih Kongresi (5-9 Eylül 1990, Ankara) Bildiriler, Ankara 1994, II, s. 718.

16 Pachymeres, a. g. e., I, 184-185; Türkçe trc. İlcan Bihter Barlas, s. 36; Shukurov, The Byzantine Turks, s. 105.

17 Turan, a. g. e., s. 498; Dimitri Korobeinikov, Byzantium and The Turks in the Thirteenth Century, Oxford 2014, s. 205. 
Han'ın baskılarını hissediyor, hatta ondan korktuğu için kızı ile Hülâgû Han arasında evlilik bağı tesis ederek endişelerini azaltma yoluna gidiyordu. Kızını zengin hediyeler ile Hülâgû Han'ın yanına göndermişse de alay yolda iken Hülâgû'nun vefat haberi geldi ve İmparatorun kızı bu durumda Hülâgû Han'ın oğlu Abaka Han (1265-1282) ile evlendirildi. ${ }^{18}$ Ayrıca Moğollarla olan işbirliğinin de etkisiyle Bizans İmparatoru'nun II. İzzeddin Keykâvus'a karşı olan tutumu değişmeye başladı ve çok geçmeden de II. İzzeddin Keykâvus ile ailesi isyan teşebbüsü şüphesiyle hapsedildi. ${ }^{19}$

Bununla berâber II. İzzeddin Keykâvus'un Anadolu'da bıraktığı maiyetinden birçok kimse İstanbul'a gelerek onun hizmetine girmiş destekçileri çoğalmıştı. ${ }^{20}$ Bu münâsebetle Sultan II. İzzeddin Keykâvus'un Konya'dan ayrılışı ve İstanbul'da yaşadığı hâdiselerin akabinde Sarı Saltuk'un (ö. 697/1297-1298) müritleri ve Türkmenler (rivâyete göre 12.000 kişi) ile birlikte Dobruca ve kuzeyindeki Babadağı civarına gittikleri ve bu bölgeye de "Baba Saltuk beldesi" adı verildiği; Sarı Saltuk'un Balkanlar'da İslâmiyeti yaydığı cihatlar yaptığına dâir rivâyetler ve menkıbeler kaynaklara intikal etmiştir. ${ }^{21}$

\section{Sarı Saltuk ve Berâberindeki Türkmenlerin Balkanlara Geçişleri Hususunda Kaynak ve Araştırmalarda Yer Alan Görüşler Üzerine}

Her ne kadar özellikle Sarı Saltuk hakkında mâlûmat veren eserler çalışmanın konusunu oluştursa da dönemin birinci elden kaynağı olması ve yaşanan siyasî gelişmelerin daha iyi anlaşılabilmesi açısından öncelikle Selçuklu devri kaynaklarından İbn Bîbî’ye (ö. 684/1285'ten sonra) başvurulmuştur. Sarı Saltuk bahsinin yer almadığı İbn Bîbî'de İstanbul'a gittikten sonra yanına gelen destekçileri sayesinde maiyeti giderek güçlenen II. İzzeddin Keykâvus'un hapsedilmesiyle ilgili olarak şu bilgiler yer alır: "O sırada fesat beyinleri rahat durmayan bir grup, bir akşam sultan, Ali Bahadır ve sultanın şarâbsâlârı Hıristiyan Kir Kedîd (sultanın dayısı) ile birlikte şarap içtikleri sırada aralarında 'Atalarının ülkesinden uzaklaşıp onların tahtından mahrum kalmasına rağmen Allah'ın destek ve yardımıyla sultanın saltanatına bağlı olan taraftarlarının sayısı büyük bir çoğalma gösterdi. Eğer bir fırsatı bulunur, Palaiologos gezinti (seyran) yerinde ortadan kaldırılırsa, bu ülkenin padişahlığı sultana geçer ve burası onun eski ülkesine katılır' dediler. Bu sözleri hilekâr ve iki yüzlü bir tabiata sâhip olan Kir Kedîd, ertesi gün imparatora duyurdu. Palaiologos bu gammazlığı dikkate alarak fırsat kollamaya başladı. Bir gün bir bahaneyle Emîr-i Âhur Uğurlu ile Ali Bahadır'ı yanına çağırarak onları tutukladı. Sultanın kapısına gardiyanlar gönderdi. Birkaç gün sonra onu, annesinin, Gıyâseddin Mesud ve Rükneddin Geyûmers adlı iki oğluyla birlikte bir kaleye hapsetti. Emîr-i Âhur'un gözlerine mil çektirip, Ali Bahadır'ı öldürttü. "22

18 Pachymeres, a. g. e., I, 234-235; Türkçe trc. İlcan Bihter Barlas, s. 39-40.

19 İbn Bîbî, a. g. e., II, 161; Yusuf Ayönü, Selçuklular ve Bizans, Ankara 2014, s. 257-269.

20 Pachymeres, a. g. e., I, 234-235; Türkçe trc. İlcan Bihter Barlas, s. 39-40; Ekici, a. g. e., s. 57-58.

21 Turan, a. g. e., s. 580-581.

22 İbn Bîbî, a. g. e., II, 161. 
Dönemin Bizans kaynaklarından Pachymeres'de (ö. [1310?]) uzun süre kaldığı İstanbul'da Sultan II. İzzeddin Keykâvus'un her geçen gün hatırı sayılır bir kuvvet temin ederek geri döneceğine dâir umutlarının tükendiğinden bahsedilmektedir. Çünkü imparatorun kızını evlendirerek ittifak kurmak gibi başka amaçları bulunmaktadır ve Abaka Han ile tesis edilecek evlilik bağı gerçekleşirse sultanın bir daha ülkesine geri dönemeyeceği aşikâr olacaktır. Yaşanan gelişmeler şu ifâdelerle zikredilmiştir: “imparatoru ortadan kaldırmak üzere harekete geçen sultan, Karadeniz'in kuzeyinde bulunan akrabalarından birinden kendisini bu çaresiz durumundan kurtarması için yardım istedi. Bu adam eğer lizzeddin'e yardım etmeyi kabul ederse, Istanbul'a gelecek ve imparatora saldırmasında ona destek olacaktı ki, Izzeddin ile ortak olmayı kabul etti. Eğer imparator ele geçirilirse saldırganlar sultanın huzuruna büyük bir ganimete sâhip olarak döneceklerdi. Sultan eski ününü ve dostlarını geri istiyordu. Dönüşte bu büyük kazanımlara sâhip olma umuduyla yola çıkacaktı. Düşüncelerini gizlice akrabasına anlatıp mektupla ondan teminatlar aldıktan sonra imparatoru görmek istemiş, imparatora mektup yazarak onun yanına gitme isteğini bildirmişti. Çünkü uzun zamandır ondan uzakta bulunmaktaydı. Bu istek onu sürekli güdülediğinden gelmesi için emir verilmese bile yine de gidecekti. Bu talebi öğrenen ve bir şeyler döndügünnden şüphelenen imparator, sultanın yanına gelmesi için mektupla izin yolladı. Bu doğuda yaşayan İzzeddin için batıyı görme fırsatıydı. Bu izinden aldığı güçle paraları, eşlerini, çocukları, kardeşini ve annesini bırakıp, engelleri kaldırmak için gerekli olan şüpheleri dağıtarak, yola çıkmaya karar vermiş, yandaşlarılla şehri terk ederek imparatora gitmek için acele etmişti. ${ }^{23}$ Hâdiselerin devamında da Pachymeres, imparatorun suikast plânlarını öğrendiği sultan ve adamlarını hapsettiklerini ifâde etmiştir. Bu noktada dikkat çeken bir husus ise Pachymeres'in eseri üzerine araştırmalar yapan ve orijinal metinleri ile Fransızca tercümesini notlarılla birlikte yayımlayan Albert Failler'in Sarı Saltuk'u Sultan II. İzzeddin'in amcası olarak tavsif etmesidir. ${ }^{24}$

Bir diğer Bizans kaynağı Gregoras'da da (ö. 1360) yine doğrudan Sarı Saltuk'un ismi zikredilmemişse de kardeşiyle yaşanan mücâdeleler üzerine ülkesinden ayrılmak zorunda olan Sultan II. İzzeddin'in mülteci olarak Bizans İmparatoru Palaiologos'a sığındığı ve aralarındaki eski münâsebetlerden dolayı imparatorun misafirperverliğiyle karşılaştığ ${ }^{25}$ ayrıca II. İzzeddin Keykâvus'u takip eden ve Hıristiyanlığa geçmiş Türkopollerin Bizans bayrakları alıında düşmanlara karşı mücâdele ettikleri yer almaktadır. ${ }^{26}$ Eserde Bizans İmparatorluğu'na askerî yardımlarda bulunmuş olan Türklerin coğrafî olarak hangi bölgelerde Bizans İmparatorluğu'nun düşmanlarıyla mücâdele ettiklerine dâir herhangi bir ayrıntı verilmemiştir.

Sarı Saltuk ile mektuplaştıklarını ifâde ederek onu bizzat tanıdığını belirten İbnü's-Serrâc (ö. 747/1346), Sarı Saltuk ve Sultan II. İzzeddin Keykâvus arasındaki münâsebetlerden bah-

23 Pachymeres, a. g. e., I, 300-303; Türkçe trc. İlcan Bihter Barlas, s. 44.

24 a. g. e., I, 301 n:6; Türkçe trc. Illcan Bihter Barlas, s. 44 n: 42.

25 Nikephoros Gregoras, Corpus Scriprorum Historiae Byzantinae, ed. L. Schpon, Bonnae 1829, I, 82.

26 a.g.e., I, 101. 
setmemiş olmamakla berâber evliyâların büyüklerinden olan şeyhin vefatına kadar yaşadığı Balkanların kuzeydeki yerleşim yerleri ile ilgili olarak çeşitli bilgiler vermektedir. Kayda göre; Sarı Saltuk, Sakçı ${ }^{27}$ denilen ve Akçakerman'ın batısında ${ }^{28}$ bulunan küçük bir şehirde yaşamış, Şeyhin türbesi de Sakçı'ya yaklaşık üç saat mesâfede bulunmaktaydı. ${ }^{29}$ İbnü's-Serrâc ayrıca Sarı Saltuk'u evliyânın büyüklerinden, her zaman geçerli güzel menkıbeleri olan tarikat önderlerinden ve seçkin şahsiyetlerinden olduğunu zikretmiştir. ${ }^{30}$ İbnü's-Serrâc, Sarı Saltuk'un ismini zikrederek o ve berâberindeki Türkmenlerin Dobruca civarına göç ettiklerinden bahseden en eski müelliftir.

İbn Battûta (ö. 770/1368-1369) Seyahatnâmesi'nde geçen “Nihâyet Baba Saltuk adıyla bilinen ve Türklerin yaşadıkları toprakların sonu olan kasabaya geldik... Onların inançlarına göre Baba Saltuk olağanüstü güçlere sâhip, kerametli biriymiş. Lâkin hakkında söylenenler dinin temel prensipleriyle bağdaşmamaktadır. Baba Saltuk'la Bizans'ın ilk vilayeti arasında, normal yürüyüşle 18 gün tutan bomboş bir bozkır var. Buranın sekiz günlük kısmı sudan yoksundur; hiçbir yerde şöyle dikili bir ağaç dahi göze çarpmamaktadır... Önümüzdeki bozkırı göze alarak Baba Saltuk Kasabası'nda tüm hazırlıklarımızı yaptık"31 ifâdeleriyle Balkanlar'daki Türk varlığından bahsetmekle berâber Sarı Saltuk'un bölgeye nasıl geldiği ve Selçuklu Sultanı ile münâsebetleri hakkında herhangi bir mâlûmat vermemektedir. Bununla berâber İbn Battûtâ'nın, İbnü's-Serrâc'ın kayıtlarında da geçen bölgelere artık Sarı Saltuk'un nâmı sayesinde "Baba Saltuk" adının verildiğini vurgulaması Sarı Saltuk'un kısa zamanda ne kadar önemli faâliyetlerde bulunduğunu da göstermektedir.

Sarı Saltuk hakkında bilgi veren XV. yüzyıl müverrihlerinden Yazıcızâde'de geçen bilgilere göre: "Bir gün Sultan İzeddin Keykâvus ve Emîr Ali Bahadır, imparatora giderek; 'Biz Türk taifesiyiz, şehirde duramayız, dışarıda ise bize yer ve yurt olsa Anadolu'dan bize taalluk Türk obalarını getirip onla yaylar ve kışlarız' dediler. Imparator Mikhail Palaiologos Dobruca ilini onlara yer ve yurt olarak verdi. Bunun üzerine Türk obalarına el altından haber ettiler, İznik ve Üsküdar üzerinden az müddetle çok Türk evi göçtü. Sarı Saltuk onlarla geldi. Dobruca ilinde iki üç pare Müslüman şehri 30-40 bölük Türk obaları vardı."32 Yazıcızâde bu bilgilere ilâveten gelen kafilenin imparatorun düşmanlarına cevap vererek onları kahrettiklerini de belirtmiş-

27 Sakçı'nın Dobruca'nın kuzeyinde bulunan İsakça Kasabası olduğu düşünülmektedir. Bkz. Ebül-Fidâ, (Takvîmü'lBüldân, Türkçe trc. Ramazan Şeşen, Ebü'l-Fidâ Coğrafyası, İstanbul 2017, s. 189-190) enlem ve boylamına göre konumunu verdiği Sakçı'nın Tuna Nehri'nin Karadeniz'e döküldüğü yerin yanındaki düz arazide, Kaşka dağı eteğinde olduğunu kaydeder; Bogdan Murgescu, “isakça”, DiA, XXII, 489-490; M. Kiel'de ("Sarı Saltuk”, DiA, XXXVI, 148) İbnü's-Serrâc'ın verdiği bilgilere göre Sarı Saltuk'un eski adı İsakça olan Dobruca'da yaşadığını ve vefat ettiğinde inzivaya çekildiği dağın yakınlarında gömüldüğünü belirtmektedir.

28 Ebül-Fidâ, (a. g. e., s. 189) Akçakerman'a beş günlük mesâfede olduğunu zikreder.

29 İbnü's-Serrâc, Tuffâhu'l-Ervâh ve Miftâhu'l-Irbâh, Ruhların Meyvesi ve Kazancın Anahtarı, Türkçe trc. Nejdet Gürkan-Mehmet Necmettin Bardakçı-Mehmet Saffet Sarıkaya, İstanbul 2015, s. 325-326.

30 a. g. e., s. 324-325.

31 İbn Battûta, İbn Battûta Seyahatnâmesi, Türkçe trc. A. Sait Aykut, İstanbul 2004, I, 498.

32 Yazıcızâde Ali, Tevârîh-i Âl-i Selçuk, (Selçuklu Tarihi), nşr. Abdullah Bakır, İstanbul 2009, s. 772. 
tir..$^{33}$ Mezkûr kaynakta II. İzzeddin Keykâvus ve taraftarlarının çoğalması ile bazı söylentilerin ortaya çıktığı da rivâyet edilmiştir. Şöyle ki: "Sultan Izzeddin ile emîrlerinden Ali Bahadır işretle meşgul oldukları sırada Sultan Izzeddin'in taraftarlarından bazıları '12.000 er varız, eğer fırsat gözleyip Palaiologos'u seyrana götürürseniz bu memleketin padişahlığı külliyen sultanın olur. Ondan sonra Anadolu'ya dahi firsat bulunur' diyerek isyan çıkaracaklarının işaretlerini vermiştir. Olayları işiten şarabdâr, Rûm olması hasebiyle ertesi gün imparator Palaiologos'un katına çıkarak durumu anlatmıştır. Akıllı bir imparator olan Palaiologos birkaç gün fırsat gözledi. Bir gün bir bahaneyle Emîr-i Âhur Uğurlu Beyi ve Ali Bahadır'ı yakalayıp hapsetti. Sultanın Istanbul'daki evine görevliler gönderdi. Birkaç gün sonra sultanı iki oğluyla bir karanlık kaleye hapsetti. Sultanın annesi iki küçük oğluyla İstanbul'da kendi evinde kaldı. Sultan iki oğlu Gıyâseddin Mesud ve Rükneddin Geyûmers ile o kalede mahpus kaldı. Birkaç gün sonra Emîr-i Âhur'un gözlerine mil çekildi. Ali Bahadır öldürüldü. İslâm'a devam edenler zindanda kaldı." ${ }^{34}$ Yazııızâde rivâyetini bu noktada bırakarak diğer hâdiselere geçer; ancak ilerleyen bölümlerde II. İzzeddin Keykâvus'un oğlu Gıyâseddin Mesud'un hükümdarlığı (1282-1296, 1302-1308) döneminde İstanbul'da kalan sultanın kardeşinin birkaç Türk ile kaçmaya azmettiğini de zikreder. Buna göre; imparator İstanbul'da kalan Selçuklu Meliki'ni tutup hapsetmiş çok geçmeden de melik, patrik tarafından hapisten kurtarılarak vaftiz edilmiş ve keşiş suretiyle Hıristiyanlığa hizmet etmeye başlamıştı. Sarı Saltuk onu patrikten istemiş talebi kabul edilince de sultanın kardeşi Sarı Saltuk katına gönderilerek yeniden Müslüman olmuştu. Sarı Saltuk şehzâdeye Barak $^{35}$ nâmıyla hitap ederek onu Sultâniye taraflarına göndermişti. ${ }^{36}$

33 a.g.e., s. 773.

34 a.g.e., s. 773.

35 Barak Baba olarak nâm salan bütün Anadolu'yu gezen, İlhanlılar tarafından hüsn-ü kabul gören Türkmen babasının Selçuklu şehzadesi olduğuna dâir mâlûmat hakkında ayrıca bkz. Müneccimbaşı Ahmed b. Lütfullah, Câmiu'd-Düvel, yay. ve Türkçe trc. Ali Öngül, Câmiu'd-Düvel Selçuklular Tarihi Il, Anadolu Selçukluları ve Beylikleri, İstanbul 2017, II, 97; krş. Ahmet Yaşar Ocak, Sarı Saltık Popüler İslâm’ın Balkanlar'daki Destanî Öncüsü (XIII. Yüzyıl), Ankara 2011, s. 70-74; a. mlf., "Barak Baba”, DiA, V, 61-62.

36 a. g. e., s. 853, 855. Sultâniye, Kazvin ile Tebriz arasında yer almaktadır ve Olcaytu Han (1304-1316) döneminde İlhanlıların devlet merkezi buraya nakledilmiştir. Bkz. Abdülkadir Yuvalı, “ilhanlılar”, DIA, XXII, 103. 
Sarı Saltuk'un menkıbelerinin toplandığı Saltuknâme'nin ${ }^{37}$ müellifi Ebü'l-Hayr-ı Rûmî ${ }^{38}$ (ö. IX. / XV. yüzyıl), Cem Sultan'ın (ö. 900/1495) Edirne'de bulunduğu sırada Sarı Saltuk'un müritlerinden menkıbeleri dinlediğini ve onları çok beğenmesi üzerine bizzat Cem Sultan tarafından sözlü rivâyetleri derleyip bir kitap haline getirmekle vazifelendirildiğini Saltuknâme'de belirtmiştir. Ebü'l-Hayr-ı Rûmî belde belde dolaşarak Sarı Saltuk'un menâkıbını tespit etmiştir. Nitekim Saltuknâme'nin daha ilk sayfalarından itibaren Sarı Saltuk'un Rumeli'deki gazâları, faâliyetleri, savaşları anlatılmakta; Rumeli hakkındaki bilgiler, tarihî gerçekler ve efsane ile karışık bir şekilde yer almaktadır. ${ }^{39}$

Osmanlı Şeyhülislâmı ve tarihçisi olan Kemalpaşazâde (ö. 940/1534) de eserinde Sarı Saltuk'u zikrederek “Sinop Samsun gibi şehirlerden Rumeli'ye Dobruca'ya doğru halkın yöneldiği ve seçkin erdemleri, faziletleri olan Sarı Saltuk'un etrafında parlak savaşçılarla birlikte toplandıklarını" belirtmiştir. ${ }^{40}$ Pachymeres'de Sultan II. İzzeddin Keykâvus'un Karadeniz'in kuzeyindeki akrabalarından yardım istediği zikredilirken Osmanlı dönemi kaynağında ise daha geniş bir şekilde hangi şehirlerden Dobruca'ya doğru Türkmenlerin göç ettiği belirtilmiştir.

Lokmân b. Hüseyin'in (ö. 1010/1601'den sonra) Oğuznâmesi'nde Sarı Saltuk'un bazı Türk obaları ile Rum iline geçip Dobruca bölgesinin sakini olduğu bilgisi verilmiş, ardından da "Sarı Saltuk ubûri Rum iline, 662 idi hemân"/11 dizeleriyle Sarı Saltuk'un bölgeye geldiği yıl 662 (4 Kasım 1263-23 Ekim 1264) olarak gösterilmiştir. Bu hususta kıymetli araştırmalar yapmış Shukurov'a göre; diğer tarihî kaynaklar incelendiğinde Lokmân b. Hüseyin'in gösterdiği mezkûr tarih elde edilen bilgilerle uyuşmaktadır.42 Nitekim eser doğrudan tarih bilgisi vermesi açısından ayrı bir öneme sâhiptir. Eserde zikredilen diğer bilgiler ise Yazıııâde'nin kayıtları ile benzerlik göstermektedir.

37 Ebü'l-Hayr-ı Rûmî, Șaltuk-Nāme: The Legend of Șarı Șaltuḳ Collected from oral tradition by Ebü'l-Hayr Rūmī, nşr. Fahri İz-Şinasi Tekin, Gönül A. Tekin, Cambridge, Mass 1974-1984; a. mlf., Saltuknâme, nşr. Şükrü Halûk Akalın, Ankara 1987-189, I-III; a. mlf., Saltıknâme (Saltık Gazi Destanı), nşr. Necati Demir-M. Dursun Erdem, İstanbul 2013, I-III. Saltuknâme hakkında ayrıca bkz. Kemal Yüce, Saltuk-nâme’de Tarihî, Dinî ve Efsanevî Unsurlar, Ankara 1987; M. Fuad Köprülü, “Anadolu Selçukluları Tarihi'nin Yerli Kaynakları I”, Belleten, C. VII, Sayı: 27, Ankara, 1943, s. 430441; Şükrü H. Akalın, “Ebü’l-Hayr-ı Rûmî’nin Saltuk-Nâme'si”, Türk Dili Araştırmaları Yıllığı Belleten, C. XL, (Ankara 1992), s. 37-59; I. Mélikoff, "Qui était Sarı Saltuk? Quelques Remarques sur les Manuscrits du Saltukname”, Studies in Ottoman History in Honour of Prof. V. L. Mélange, ed. C. Heyvood-C. Imber, İstanbul 1994, s. 231-238; Şükrü H. Akalın, "Saltukname'ye Göre Sarı Saltuk", Balkanlara Gidişinin 750. Yılında Uluslararası Sarı Saltuk Gazi Sempozyumu (06-10 Kasım 2013, Köstence-Romanya) Bildiriler, Edirne 2014, s. 351-363; Ahmet T. Karamustafa, "Islamisation through the Lens of the Saltuk-name", Islam and Christianity in Medieval Anatolia, ed. A. C. S. Peacock, Bruno de Nicola, Sara Nur Yıldız, Farnham 2015, s. 349-364; Aybeniz Rahimova, “Oğuzların Dini Kahramanlık Destanı Saltukname”, Türk Dünyası Araştırmaları (TDA), C. 123, Sayı: 243, (Kasım-Aralık 2019), s. 249-25.

38 Müellif hakkında bkz. Necmettin Turinay, “Saltıkname'nin Meçhul Yazıcısı: Ebulhayr-ı Rumî”, 2. Uluslararası Sarı Saltuk Gazi Sempozyumu (06-09 Mayıs 2015, Saraybosna-Bosna Hersek) Bildiriler, Edirne 2015, s. 201-220; Şükrü H. Akalın, “Ebülhayr Rûmî”, DiA, X, 360-362.

39 Şükrü H. Akalın, “Balkanlarda İslâm'ın ve Türklüğün Yayılmasında Bir Öncü: Sarı Saltuk”, ed. M. Savaş Kafkasyalı, Balkanlarda İslâm Miadı Dolmayan Umut, Ankara 2016, II, 61-62.

40 Kemalpaşazâde, Histoire de Campagne de Mohacz, nşr. Pavet de Courteielle, Paris 1859, s. 77.

41 Lokmân b Hüseyin, Seid Locmani ex Libro Turcico qui Oghuznāme inscribitur excerpta, nşr. J. J. Wilhelm Lagus, Helsiogforsiae 1854, s. 3.

42 Shukurov, The Byzantine Turks, s. 124. 
Lokmân b. Hüseyin'e göre; Sultan II. İzzeddin Keykâvus, Antalya'dan berâberinde yakınları ve vâlidesiyle Palaiologos katına İstanbul'a gitmiş, imparator onu izzet ve ikramla ağırlamış, sultan ve diğer misafirlerine nimetler döküp bahşişler vermiştir. Ancak onlar rahata düşerek vatanlarını unutmuşlar, günlerini işretle geçirir olmuşlardı. Emîr-i Âhur Uğurlu ile Ali Bahadır sultanın yanına geldiklerinde ise Bizans İmparatoru Rumeli'deki düşmanlarıyla cenk için Ali Bahadır'ı göndermişti. Ali Bahadır elde ettiği başarılarla imparatorun gözünde yükselmişti. Nihâyetinde bir gün "Sultan Izzeddin ve Ali Bahadır, Palaiologos'un huzuruna çıkarak: 'Biz Türk taifesiyiz, daima şehirde duramayız, bize bir yer yurt tayin olsa Anadolu'dan bize taalluk eden Türk evlerini getirip onda yaylar ve kışları' dediler. İmparator da Dobruca yöresini onlara yer yurt olarak verdi. Anadolu'dan kendilerine katılacak Türk obalarına el altından haber ettiler. Kışlak bahanesiyle Sarı Saltuk ile Iznik'e geçip oradan Izmit'e ardından da Üsküdar üzerinden Dobruca'ya geldiler. Dobruca ilinde iki üç pare Müslüman şehri 30-40 bölük Türk obaları vardır. Palaiologos'un düşmanlarına cevap verip kahrederlerdi". ${ }^{43}$ Hâdiselerin devamında da bir gece Sultan İzzeddin ile Ali Bahadır'ın işretle meşgul oldukları sırada meclistekilerinden bazıları sayıları 12.000'e ulaşan kuvvetleriyle imparatorun İstanbul'da olmadığı bir sırada sultanın İstanbul'un hükümranlığını hatta Anadolu saltanatını da elde edebileceğini dile getirdiler. Bizans İmparatoru bu durumu işitince sabırla bekleyip uygun fırsatı kollamış, fırsatııı bulunca da II. İzzeddin Keykâvus ve adamlarını hapsetmişti. Sultan hapisten kurtarılıp Berke Han'ın hizmetine girdikten sonra da Sarı Saltuk ile Dobruca Türklerinin Deşt-i Kıpçak'a ilerlediği zikredilmiştir. ${ }^{44}$

Evliya Çelebi'nin (ö. 1095/1684[?]) Seyahatnâmesi'nde de her ne kadar Balkanlara geçiş süreci hakkında mâlûmat bulunmasa da eserde Muhammed Buharî olarak geçen Sarı Saltuk'un Balkanlar'da İslâmiyeti yaymak üzere yürüttüğü faâliyetler ve Sarı Saltuk'a atfedilen türbelerden bahsedilmektedir. ${ }^{45}$

Çok sayıda araştırmada yer bulan II. İzzeddin Keykâvus'un İstanbul'a geçişinin akabinde yaşanan göçlerle ilgili olarak J. Von Hammer, Sarı Saltuk Dede idâresindeki Türk kuvvetlerinin, İzzeddin Keykâvus'un Kırım'a götürüldüğü dönemde Karadeniz' in Batı kıyısında yer alan Dobruca Tataristanı denilen yörelere 662 (1263) yılında yaklaşık 12.000 Türkmenin yerleşmiş olduklarıı belirtir. İstanbul'da mülteci konumunda olan II. İzzeddin bu yeni takviye güçlere itimat ederek müsteşarı Ali Bahadır ile birlikte Bizans İmparatoru'na bir komplo kurma girişimine karışmış ve sultan kendi hizmetkârları tarafından ihanete uğramıştır. Yaşanan gelişmelerin akabinde II. İzzeddin Keykâvus'un hapse atılmasından sonra ise Dobruca'daki kuvvetlerin bir kısmı Hıristiyanlaştırılmıştır. ${ }^{46}$

43 Lokmân b Hüseyin, a. g. e., s. 9-10.

44 Lokmân b Hüseyin, a. g. e., s. 10-11.

45 Evliya Çelebi, Günümüz Türkçesiyle Evliyâ Çelebi Seyahatnâmesi: Akkirman-Belgrad-Gelibolu-Manastır-ÖzüSaraybosna-Slovenya-Tokat-Üsküp, haz. Seyit Ali Kahraman, 5. Cilt 1. Kısım, İstanbul 2010, 308. Ayrıca bkz. Helga Anetshofer, "Legends of Sarı Saltık in the Siyasetnâme and the Bektashi Oral Tradition", Evliyâ Çelebi Studies and Essays Commemorating the the 400th Anniversary of his Birth, ed. Nuran Tezcan vd., İstanbul 2012, s. 296-304.

46 J. Von Hammer, Histoire de L'Empire Ottoman: Depuis Son Origine Jusqu'à nos Jours, Paris 1840, I- 20; IV 57-58. 
Ahmed Tevhid, Sultan II. İzzeddin Keykâvus ile Sarı Saltuk arasındaki münâsebetlerine değinmemiş olsa da Lokmân b. Hüseyin ve Yazıcızâde'yi kaynak göstererek Dobruca'da Sarı Saltuk'un ve berâberindeki Türklerin 662 (1263-1264) senesinde geldiklerine değinmiştir. ${ }^{47}$

J. Deny'e göre Sarı Saltuk, XIII. yüzyılda Selçuklu Türklerinin göçüne yol açan gizemli bir şahsiyettir. XIII. yüzyılda kardeşi tarafından ülkesinden çıkarılan II. İzzeddin Keykâvus yanındaki sadık kişilerle Bizans İmparatoru'na sığınır. Yeni gelenlerin imparatora verdiği hizmetler imparatorun onların Dobruca'ya koloni getirmelerine ve yerleşmelerine izin vermesini sağlamıştır. Bu izinle birlikte İznik ve İzmit üzerinden Selçuklu Türkleri başlarında kutsal bir şahsiyet olan (evliyâ) Sarı Saltuk'la birlikte Dobruca'ya ulaşmışlardır. ${ }^{48}$

Bilhassa Yazıcızâde'de geçen mâlûmatı derinlemesine inceleyen ve değerlendiren Paul Wittek, öncelikle Yazıcızâde'nin verdiği bilgileri ortaya koymuştur. Ardından da çeşitli tespit ve değerlendirmelerde bulunmuştur. Wittek'in incelemiş olduğu Yazıcızâde nüshalarına göre: “Bir gün sultanın maiyetindeki komutanlardan biri, Imparator Palailogos'a, Türklerin şehir hayatına sonsuza kadar dayanamayacakları yönünde şikâyet ediyordu. Eğer imparator yerleşmeleri için mesken verirse göçebe ailelerini Anadolu'dan çağırabilirlerdi. Palailogos onların Dobruca'ya yerleşmelerine olanak sağlar. Bunun üzerine kalabalık kafileler dağlardan İnik'e inip, Üsküdar'dan karşıya geçerler. Kutsanmış (aziz) olarak kabul edilen Sarı Saltuk da onlarla birliktedir. Dobruca'da iki veya üç Müslüman kasaba ahalisi ve Türk göçebelerinden 30-40 obadan müteşekkil Türkler, imparatorun düşmanlarını uzaklaştırıyor ve yok ediyordu. Ancak bir ziyafet sırasında (İstanbul') sultan, maiyetindekiler tarafından kendisini destekleyenlerin gücüyle kâr etmeye ve Palailogos'u devirmeye teşvik edilir. Bu durumun neticesinde Bizans Imparatoru Türk kuvvetlerinin iki komutanından birinin öldürülmesini, diğerinin de kör ettirilmesini emreder bununla berâber yalnızca vaftiz olmayı kabul eden Türk askerlerinin imtiyazını verir. Sultan ve iki oğlu, Mesud ile Geyûmers, bir kalede hapsedilir. Dobruca'daki Türkler orada Sarı Saltuk ile kalırlar"ı9 ifâdeleriyle Sarı Saltuk'un sultanın hapsedildiği dönemdeki varlığından bilgiler aktarmaktadır. Yazıcızâde'deki bilgilerin devamında da yer alan II. İzzeddin Keykâvus'un ölümünden sonraki gelişmeler anlatılırken Gıyâseddin Mesud'un Anadolu'ya geçmek için izin isteğinin kabul edilmesiyle Sarı Saltuk'un Berke Han'ın emriyle göçebe halkını berâberindeki hayvanlarıyla meskenleri olan Dobruca'ya götürdüğü yer alır. ${ }^{50}$ Ayrıca Dobruca ve çevresine Türkmenlerin yerleşmesi ile ilgili olarak şu tespitlerde de bulunur: Göçebeler, Bizans-Selçuklu sınırını geçtikleri için Bulgarlar da Dobruca'ya doğru hareket etmişler ve açıkça göçmenler yeni evlerinde imparatorun düşmanlarıyla savaşmak zorunda kalarak sıkıntıya düşmüşlerdi. Dobruca, İstanbul'a uzak mesâfesi ve Balkanlar'daki diğer düşmanlarıla mücâdeleleri için

47 Ahmed Tevhid, “Rum Selçûkî Devleti'nin İnkırâzıyla Teşekkül Eden Tavâif-i Mülûk'den Karahisar-ı Sâhib'de Sâhibataoğulları", Târîh-i Osmânî Encümeni Mecmuası (TOEM), C. II, Sayı: 9, İstanbul 1329, s. 565.

48 J. Deny, "Sari Saltiq et le nom de la ville de Babadaghi", Mélanges Offerts a M. Émile Picot, Paris 1913, II, 1-2.

49 Paul Wittek, "Yazijioghlu 'Alī on the Christian Turks of the Dobruja”, Bulletin of the School of Oriental and African Studies (BSOAS), XIV/3, (1952), s. 648.

50 Wittek, a. g. m., BSOAS, XIV/3, s. 648. 
Bizans açısından avantajlı bir konumdaydı. Tatar saldırılarına karşı da engel oluşturabilecek pozisyonu Bizans'in Türk kafilelerini bu bölgeye yerleştirmesinde son derece elverişli olmuştu. ${ }^{51}$ Nitekim bahsettiğimiz kaynaklardan Gregoras'ta da herhangi bir tarih vermeden Türkmenlerin Bizans'ın düşmanları ile mücâdele ettiği bilgisi yer almaktaydı.

M. Fuad Köprülü, Türk Edebiyatında ilk Mutasavviflar, eserinde bilhassa Evliyâ Çelebi'ye dayanarak Sarı Saltuk menkıbesine yer vermiştir. "Evliyâ Çelebî̀nin tespit ettiği şekle göre, Ahmed Yesevî, Hacı Bektaş'tan sonra "Sarı Saltık" lakâbı ile tanınan Muhammed Buhârî̀yi Horasan erenlerinden 700 kişi ile ona imdâda gönderiyor ve meşhur tahta kılııını Sarı Saltık'ın beline kuşatarak şu nasihati veriyor: “Saltık Muhammed'im! Bektaş'ım seni Rum'a göndersin. Leh diyârında dalâlet-âyîn olan Sarı Saltık sûretine girip, ol melûnu bir tahta kılıçla katleyle! Makedonya, Dobruca'da, yedi-krallık yerde nam ve şan sâhibi ol!" Sarı Saltık, Rûm diyârına gelince, Hacı Bektaş Velî, şeyhinin emrini yerine getirerek, onu Dobruca'ya gönderiyor; o da oralara giderek birçok kerametler gösteriyor, birçok yerleri zapt ve ahâlisini İslâm eyliyor. ${ }^{152}$

Osman Turan, II. İzzeddin Keykâvus'un Konya'dan ayrıışı ve gurbet hayatında yaşadıkları ile bağlantılı olarak “meşhur Türkmen babası Sarı Saltuk'un bir kısım müridleri ve Türkmenleri (rivâyete göre 12.000 kişi) ile birlikte Dobruca'ya gittikleri ve bu bölgeye de 'Baba Saltuk beldesi' adı verildiğini, onun Balkanlar'da Islâmiyeti yaydığını" ifâde etmiştir. ${ }^{53}$

Tayyip Okiç, “Sarı Saltuk'un bazı Türk aşiretleriyle birlikte 662 (1263) yılında Avrupa'ya geçtiği tarihen sabittir. O kendisinden çok daha evvel buralarda bulunan ve zamanında sönmeye mahkûm bir duruma girmiş olan bazı İslâm kolonilerini tekrar kurmak ve canlandırmak, hatta bununla da iktifa etmeyerek, kuzeyden güneye kadar her tarafta İslâm' I yeniden yaymak hususunda faâliyete geçen kahraman ve büyük bir İslâm misyoneridir" 54 ifâdeleriyle Sarı Saltuk'u tavsif etmiştir. "Bazı Türk aşiretlerinin Bizans hizmetine girerek Balkanlar'ın muhtelif mıntıkalarına iskân edilmelerinin örneklerine tekrar tekrar rastlandığını; 662 (1263) senesinde Sarı Saltuk ile birlikte bazı Türklerin bu şekilde Balkanlar'a geçerek orada yerleşmiş oldukları hakkında Bizans ve İslâm kaynaklarında tarihî kayıtların mevcut olduğunu" vurgulamıştır. Bu açıklamaların ardından daha ziyade Sarı Saltuk'un Balkanlar'da ve diğer Avrupa mıntıkalarındaki dinî misyonuna değinilmiştir. ${ }^{55}$

Romen tarihçi Aurel Decei de araştırmasında Osmanlı Devleti'nin bölgeyi fethine kadar İzzeddin Keykâvus'un Türklerinin Dobruca'da İslâmiyeti devam ettirdiğini ifâde etmiş, karşı-

51 Wittek, a. g. m., BSOAS, XIV/3, s. 654-655.

52 M. Fuad Köprülü, Türk Edebiyatında Illk Mutasavviflar, Ankara 1976, s. 54-55. Köprülü, (a. g. e., s. 55 n. 62) "Hakikaten bu menkıbenin tarihî bir esası bulunmaktadır" diyerek devamında şöyle ifâde etmiştir: "Hicrî 662 (M. 1263-1264) tarihinde birtakım Türkler Sarı Saltık'un maiyetinde Dobruca'ya geçmişler ve sonra Balıkesir'deki Karesioğullarından İsâ Bey zamanında tekrar Karesi mülküne hicret etmişlerdir."

53 a. g. e., s. 581

54 Tayyib Okiç, "Sarı Saltuk'a Ait Bir Fetva", Ankara Üniversitesi Ilahiyat Fakültesi Dergisi (AÜiFD), C. I, Sayı: 1, (1952), s. 48-49.

55 Okiç, a. g. m., AÜiFD, C. I, Sayl: 1, s. 51-52. 
laştırmalı örnekler sunmuştur. Diğer araştırmacılar gibi Lokmân b. Hüseyin'den ve Osmanlı kaynaklarından verdiği mâlûmatla Sarı Saltuk'un II. İzzeddin Keykâvus'un çağrısıyla berâberindekilerle birlikte Dobruca'ya geldiğini göstermiştir. Ayrıca Osmanlı tarihlerine göre Sarı Saltuk da dâhil olmak üzere Dobruca'daki bazı Müslümanların Kırım’a gittiğinde de sultanı takip ettiklerini zikretmiştir. ${ }^{56}$

Sarı Saltuk'la birlikte Dobruca ve civarına göç eden Türklerle ilgili olarak yapılan araştırmaların bir kısmı Gagauzların etnolojisine dâir olmuş, hâdiseler Gagauzlar açısından da incelenmiştir. Gagauzların Dobruca'ya Sarı Saltuk tarafından getirilen Selçukluların bâkiyeleri olduğu kanısı hakkında Batılı tarihçilerden F. Braun, Georgi Balaschev, İ. K. Dimitrov gibi araştırmacılar tarafından çeşitli çalışmalar yapılmış; ancak bu eserlerde de genellikle Lokmân b. Hüseyin ve Yazıcızâde gibi benzer çalışmalar üzerine yoğunlaşılmıştır. P. Mutafchiev, H. W. Duda gibi araştırmacılar ise bilhassa Osmanlı dönemi tarihçilerinin görüşlerini kabul etmeyip bunların müelliflerin eklemeleri ya da hayal ürünü olduklarını savunarak eserlerinde tartışmışlardır. ${ }^{57}$

Michael Kiel, Paul Wittek'in zikrettiklerini kendi yaptığı arkeolojik araştırmalar neticesinde elde ettiği mâlûmat ile doğrulamış ve Dobruca yöresindeki Türklerden kalan eserler ve yerleşimler hakkında çalışmalarında kıymetli bilgiler vermiştir. Sarı Saltuk'un Dobruca'ya gelişi üzerine Paul Wittek tarafından da doğrulanmış olan Yazıcızâde'ye dayanarak kaleme aldığı tespitlere göre; II. İzzeddin Keykâvus'un büyük bir toplulukla birlikte Bizans'a sığınmasının ardından Bizans İmparatoru VIII. Mikhail Palailogos'un Türkleri, Bizans İmparatorluğu ile putperest Altın Ordu Tatarlarının ülkesi arasındaki, bugünkü Bulgaristan'ı oluşturan boş, sâhipsiz alana yerleştirdiğini ve Sarı Saltuk'un da onların arasında bulunduğunu zikretmiştir. XIII. yüzyılın ortalarında II. İzzeddin, Bizans İmparatoru tarafından hapsedilmiş fakat Nogay'ın Tatar ordusu, onu yeniden özgürlüğüne kavuşturmuştur. Sarı Saltuk'un önderliğindeki Müslümanlar da Dobruca'da yaşamlarını sürdürmüşlerdir. Sultan II. İzzeddin'in Kırım'a göçünün ardından ise Sarı Saltuk'un aracılığı ile henüz İslâm dinini kabul etmemiş olan Kıpçak Türklerinin güçlü başkanı Nogay'ın himâyesi altına girmişlerdir. ${ }^{58}$

Zerrin Günal Öden, bilhassa kardeşi Kılıç Arslan ile yaşanan mücâdeleler neticesinde ülkeyi terk etmek zorunda kalan zorunda kalan II. İzzeddin Keykâvus'un imparator tarafından itibarlı bir misafir olarak görüldüğünü; hatta bir süre sonra taşrada ikamet etmek isteyen

56 Aurel Decei, “Le problème de la Colonisation des Turcs Seldjoucides dans la Dobroggea au XIII siècle”, TAD, Sayl: 10, (1968), s. 85-111.

57 Bu yazarların hâdiselere bakışı hakkında bkz. M. N. Guboglo, "Gagauzların Etnik Aidiyeti”, Türkçe trc. Bülent Hünerli, TÜRÜK Uluslararası Dil, Edebiyat ve Halkbilimi Araştırmaları Dergisi, 2018, Yıl: 6, Sayı: 12, s. 67-78; Vlodzimej Zayonçkovskiy, "Gagauzların Etnogenezine Dair”, TÜRÜK Uluslararası Dil, Edebiyat ve Halkbilimi Araştırmaları Dergisi, 2018, Yıl: 6, Sayı: 14, s. 247-253. Gagauzların tarihleri hakkında ayrıca bkz. Harun GüngörMustafa Argunşah, Gagauz Türkleri, Tarih-Dil-Folklor ve Halk Edebiyatı, Ankara 1991; Bülent Hünerli, Mihail Çakir'in Gagauzca (Türkçe)-Rumence Sözlüğü (Inceleme-Metin), Çanakkale 2019, s. 2-10; a. mlf., "Gagauzlar ve Lozan Mübadelesinin Pek Bilinmeyen Bir Yönü: Yunanistan Gagauzları", Mübadil Kentler: Türkçe Konuşan Rum Ortodokslar, ed. Yonca Cingöz, İstanbul 2019, s. 88-89; Kemal Karpat, “Gagauzlar”, DiA, XIII, 288-291.

58 Michael Kiel, "Sarı Saltık ve Erken Bektaşilik Üzerine Notlar", Türkçe trc. Fikret Elpe, Türk Dünyası Araştırmaları Dergisi, C. II, Sayı: 9, 1980, s. 26-27; a.mlf. “Sarı Saltuk”, DiA, XXXVI, 147-150. 
Türklere malikâne olarak Dobruca'nın verildiğini ve II. İzzeddin'e Selçuklu tahtını ele geçirmesi için de yardım vaat edildiğini belirtmiştir. Ayrıca "plânlarını gerçekleştirmek için Sarı Saltuk Türkmenleri ve kendi hassa askerlerinin kumandanı Ali Bahadır'a güvenen Izzeddin'in Selçuklu tahtını ele geçirme ümidinin kuvvetlendiğini" de vurgulamıştır. ${ }^{59}$

István Vásáry, II. İzzeddin Keykâvus hakkında anlatılan rivâyetlere göre XII. yüzyılda Dobruca'da Selçuklu yerleşimi olasılığının mümkün olduğundan bahsederek Lokmân b. Hüseyin ve ardından da Yazııızâde de geçen nakillere yer vermiştir. Buna göre; İmparator VIII. Mikhail Palailogos, II. İzzeddin Keykâvus adına istekte bulunan Ali Bahadır'ı huzuruna kabul etmiş ve Selçukluların dileklerini yerine getirerek göçebe Türkmenlerin Aziz Sarı Saltuk'la birlikte Dobruca'ya yerleşmesine izin vermiştir. İki üç Müslüman kasabası 30-40 bölük Türk obasına yurt olmuştur. Sarı Saltuk da Balkanlar'da popüler bir karakter olarak İslâmiyet'in yayılmasında rol oynamıştır. Müslüman yerleşkelerinde ve türbelerinde onun ve müritlerinin izleri bulunmaktadır. ${ }^{60}$

Ahmet Yaşar Ocak, Sarı Saltuk hakkındaki kıymetli araştırmasında öncelikle tarihî süreç içerisinde II. İzzeddin Keykâvus'un İstanbul'a geçişini anlatmış̧ır. Buna göre; imparator bu asil misafirine ve ailesine büyük bir yakınlık göstererek onların diledikleri gibi yaşamalarını sağlamış ve bu esnada sultanın çok güvendiği iki yakın adamı, Emîr-i Âhur Uğurlu ve Ali Bahadır da sultanın yanına gelmişlerdi. İmparator emîrlere de teveccüh göstermiş buna mukabil onlar da imparatorun hasımlarına karşı savaşmışlardı. Ancak çok geçmeden bu monoton ve rahat hayatın oradan oraya muhârebe peşinde koşuşturan, başkalarını yönetmeye alışmış bu insanları sıkmaya başladığını tarihî kaynaklar ışı̆ıında belirtilmiştir. Sultan II. İzzeddin, Ali Bahadır ve Emîr-i Âhur Uğurlu ile Palailogos'un huzuruna çıkıp sürekli bir şehir hayatından ziyade “Türk taifesi” olarak yaylak ve kışlak hayatına alışık olduklarından, kendilerine kışın kışlayacak, yazın da yaylayacak bir arazi tahsis edilmesini ve Anadolu'dan kendilerine tâbi olan Türkmenleri getirterek buraya birlikte yerleşmek istediklerini bildirmişlerdi.61 “VIII. Mikhail, bu istekleri kabul ederek onlara Bizans'la Deşt-i Kıpçak arasında (bugün bir kısmı Bulgaristan'da, bir kısmı da Romanya sınırları içinde ve Karadeniz'e kıyısı olan) o vakitler gayri meskûn haldeki Dobruca arazisini tahsis etmiştir. Bunun üzerine söz konusu Türkmenler, Anadolu'dan getirilip Izzeddin'in başkanlığında Dobruca'ya yerleştirilmişlerdir." Sarı Saltuk'un tarihî rolünün de tam bu olayla başlayacağını ifâde eden Ocak, kaynaklarda geçen II. İzzeddin Keykâvus ve berâberindekilerin Bizans İmparatoru'nu devirme girişimine teşebbüs ettiklerini ve bu komplonun açığa çıkması ile "hain konukların" cezalandırıldığını zikrederek, bu hâdiselerin Dobruca'ya iskândan sonra vuku bulmuş olabileceğine şu ifâdelerle dikkat çeker: "Zira imparatorun kendisini devirmeye çalışan Izzeddin'e dostluk göstererek onlara yer yurt vermesi söz konusu olamazdı. Kaynakların zikrettiği komplo olayı var ise Izzeddin'in Anadolu'dan getirteceği aşireti yerleştirmek için

59 “Türkiye Selçuklu Sultanı II. Gıyaseddin Mesud Hakkında Bazı Görüşler", Belleten, C. LXI, Sayı: 231'den ayrıbasım, Ankara 1997, s. 287-288.

60 István Vásáry, Cumans and Tatars Oriental Military in the Pre-Ottoman Balkans, 1185-1365, Cambridge 2005, s. 78.

61 Ocak, a. g. e., s. 23-24. 
imparatordan toprak istemesinin altında hakikatte, kışlak ve yaylak hayatına duyduğu özlemden çok tasarladığı komplo için gerekli kuvveti temin etme ihtiyacı yatıyor demektir. "'22 Yine aynı eserde, Dobruca'ya yerleşimlerle ilgili olarak buradaki eski Türk nüfusunun üstüne bu defa Anadolu kökenli yeni bir katmanın eklendiği üçüncü katmanın ise XV. yüzyıldan itibaren Osmanlı fetihleriyle ilâve edileceği ayrıca Bizans İmparatoru'nun belki biraz bu sebeple, fakat daha ziyade, Deşt-i Kıpçak'taki Tatarların saldırılarından sınırlarını korumak ve onlarla kendi arasında bir savunma bölgesi yaratmak amacıyla Dobruca'yı, İzzeddin ve Türkmenlerinin yerleşmesine tahsis etmiş olabileceği de ifâde edilmiştir. ${ }^{63}$

Mehmet Suat Bal, “II. Izzeddin Keykâvus, Türkiye'ye geri dönüp yeniden hükümdar olabilmek için Türkmenlerin desteğini almayı plânladığını ve Il. İzzeddin Keykâvus'un çağrısı üzerine Anadolu'dan kalkıp, Sarı Saltuk önderliğinde Balkanlar'a göç eden ve Dobruca'ya yerleştirilen bu Türkmenlerin sultanlarına son derece sâdık olduklarını" ifâde etmiştir. Ayrıca "Dobruca'ya göç eden bu cesur savaş̧̧ılar, Balkanlar'da Türk İlâm kültürünün ilk temsilcileri olmuşlar, II. İzzeddin Keykâvus ile Dobruca'ya göç eden Türkler o bölgeye daha önce gelmiş olan Türklerle birleşerek önderleri “Keykôvus'un” isminden dolayı Gagauz olarak adlandırılmışlardır. Gagauzlar sonradan Hıristiyanlaşsa da II. İzzeddin Keykôvus'un ardından Sarı Saltuk ile göç edenlerin bir kısmı inançlarını korumuşlar ve Balkanlar'da yaymışlardır" diye ekleyerek Dobruca'ya göç eden Türkmenlerin Gagauzların atası olduğu hususundaki görüşlerini bildirmiştir. ${ }^{64}$

Rustam Shukurov öncelikle Albert Failler'in Sarı Saltuk'un sultanın amcası olduğuna dâir kanaatinin dayanaksız ve hatalı olduğuna dikkat çekerek Pachymeres'in kesinlikle aklında başka bir amca (dayı), (Kir Hâye ya da Kir Kedîd) olduğunu belirtmiştir. Ayrıca hâdiseler yaşanırken Kir Kedîd'in sultanla birlikte olduğunu zikreden İbn Bîbî̀ye güvenmemek için hiçbir sebep olmadığını da vurgulamıştır. ${ }^{65}$ "Özellikle sonraki yüzyıllarda Osmanlı geleneğinde Sultan II. İzeddin Keykâvus'u gölgede bırakacak şekilde efsanevî bir kimliğe dönüşecek Sarı Saltuk'un büyük ihtimâlle sultanı sürgünü sırasında takip eden Türk göçebe topluluklarılyla ilişkili olduğunu" da zikretmiştir. ${ }^{66}$ Göçebe Türklerin Bizans topraklarına göçüne dâir en ayrıntılı bilgilerin yine Yazıcızâde tarafından verilmiş olduğuna dikkat çekerek; “Sarı Saltuk'un manevî liderliğindeki bu göçebe grupların savaş̧̧ılarının imparatorun yanında, özellikle VIII. Mikhail Palaiologos adına Dobruca'nın fethedilmesi sırasında muzaffer savaşlara katılmış olduklarııı" vurgulamıştır. ${ }^{67}$ Nitekim tarihî kaynaklarda da Türkmenlerin Bizans adına Rumeli'de Bizans'ın düşmanlarıyla mücâdelelerde yer aldığı mâlûmatı yer almaktadır.

62 Ocak, a. g. e., s. 25.

63 Ocak, a. g. e., s. 28-29.

64 Bal, a. g. m., TAD, C. XXIV, Sayı: 38, s. 250; a. mlf., “Türkiye Selçukluları, Mısır Memlükleri ve Altın Orda Devleti'nin İlhanlılara Karşı Kurduğu Ittifak", Selçuk Üniversitesi Türkiyat Araştırmaları Dergisi, Sayı: 17, (2005), s. 304-305.

65 Rustam Shukurov, s. 112; a. mlf., "The Oriental Margins of the Byzantine World: A Prosopographical Perspective", Identities and Allegiances in the Eastern Mediterranean after 1204, ed. Judith Herrin-Guillaume Saint-Guillain, Aldershot 2011, s. 188.

66 Shukurov, The Byzantine Turks, s. 122.

67 Shukurov, The Byzantine Turks, s. 124. 
Birinci Dünya Savaşı'ndan sonra Bulgar bilim adamı Georgi Balaschev'in yer değiştiren Türk gruplarının Gagauzların ataları oldukları tezinin tamamen savunulamaz olduğunu belirten Hristi Matanov, Osmanlı, İran ve Arap kaynaklarıyla çalışmanın zorlukları olduğunu ayrıca Bizans kaynaklarında da göç hakkında yeterince bilgi bulunmadığından bahsetmiştir. Buna göre; "Devrin çağdaş kaynaklarında bu göçler detaylı olarak yer almamakta; Bizans kaynaklarında ise Sultan II. İzzeddin Keykâvus'un hayatı son derece ayrıntılı anlatılmasına rağmen Sarı Saltuk ve berâberinde gelenlerden bahsedilmemektedir. Hâdiselerden geniş şekilde bahseden Lokmân'ın Oğuznâmesi ise çok daha sonraki dönemde yazılmış durumdaydı. Aynı şekilde ibn Bîbî de Dobruca'ya gidiş hakkında bilgi vermemekte; Yazıcızâde'deki aktarımlar ise Ibn Bîbî̀nin vermiş olduğu bilgilere müellifin yaptığı eklemelerdi" şeklinde belirttiği görüşleriyle Matanov böylesine geniş çaplı bir yer değiştirme hâdisesi için güvenilir verilerin yeterince mevcut olmadığını vurgulamıştır. ${ }^{68}$

Bir diğer araştırmada ise II. İzzeddin Keykâvus'un Enez Kalesi zindanından kaçırılıp Kırım'a götürülmesinin ardından Sarı Saltuk'la berâber Dobruca'ya gelen Anadolu Türklerine ve İstanbul'da kalan sultan tebaasına baskı ve işkencelerin uygulanmış olma ihtimâlinden bahsedilmektedir. Ayrıca özellikle Sarı Saltuk'un ölümünden sonra da Hıristiyanlaştırma baskılarına maruz kalan Türkmenlerin kimisi Karesi Beyliği'ne (Biga ve Balıkesir yöresi) sığınıp kurtulmuşsa da çoğunluğu canlarını kurtarmak için din değiştirmek zorunda kalmış, bir kısmı da Deliorman'ın ormanlık sahasındaki Müslüman Peçenek köyleri civarını mesken edinerek Müslüman olarak kalmışlardır. ${ }^{69} \mathrm{Bu}$ Türkmenlerin Dobruca ve civarında yaşadığı köyler hakkında bilgiler de çalışmada bulunmaktadır. Sarı Saltuk'un önderlik ettiği topluluğun savaşmaksızın barışçıl bir yolla ilk defa Balkanlara yerleşen Müslüman topluluğu olduğu da bir başka araştırmada vurgulanmıştır. ${ }^{70}$ Necati Demir ve Necmettin Turinay'ın da Sarı Saltuk ve müritlerinin Bosna Hersek civarında izlerini süren eserlerinin ${ }^{71}$ yanı sıra VII. (XIII.) yüzyılda Balkanlara geçmiş Sarı Saltuk'un tarihî kişiliğinin, mezar ve makamlarının tanıtıldığı, Saltuknâme'nin incelendiği kıymetli araştırmaları bulunmaktadır. ${ }^{22}$ Turinay, Sarı Saltuk'un Dobruca, Kırım, Bosna Hersek, Kosova, Arnavutluk, Makedonya, Bulgaristan hatta Lehistan gibi bölgelere gitmeyip Anadolu'da kalmış olsaydı emsalleri diğer dervişlerin arasında yeterince tanınmayıp, iç ihtilâflar yüzünden de sıkıntılara düşebileceğine

68 Hristo Matanov, “Селджукски турци в Добруджа през XIII век?”, Списание Път, Sayı: 13, (2010), s. $14-21$.

69 Ahmet Cebeci, XVI. Yüzyıl Osmanlı Tahrir Defterlerine Göre Gagauzlar, Gazi Üniversitesi Sosyal Bilimler Enstitüsü, Yayımlanmamış Doktora Tezi, Ankara 2008, s. 161-162.

70 H. Musa Taşdelen, Bulgaristan, Romanya ve Kırım Müslüman Topluluklarda Sarı Saltık Algısı "Referans Kişilik Olarak Bir Kolonizatör Türk Dervişi", İstanbul 2015, s. 10.

71 Necati Demir-Necmettin Turinay, Sarı Saltuk Bosna Hercegovina, Ankara 2017.

72 Bkz. Necati Demir, Sarı Saltık Gazi, İstanbul 2015; a. mlf. "Saltuk-Nâme'nin Yeni Bulunan Altıncı Nüshası Üzerine”, Bilge, Sayı: 15, (Ankara 1998), s. 58-61; “Tarihi, Kültürel ve Destani Bir Kaynak Olarak Saltıkname”, Balkanlara Gidişinin 750. Yılında Uluslararası Sarı Saltuk Gazi Sempozyumu (6-10 Kasım 2013, Köstence-Romanya) Bildiriler, Edirne 2014, s. 155-175; "Saltık Gazi, Boşnaklar ve Bosna Hersek”, 2. Uluslararası Sarı Saltuk Gazi Sempozyumu (06-09 Mayıs 2015, Saraybosna-Bosna Hersek) Bildiriler, Edirne 2015, s. 177-200. 
dikkat çeken tespitlerde bulunmuştur. ${ }^{73}$ Nitekim bahsi geçen tüm ülkelerde Sarı Saltuk'un izleri görülmektedir.

Haşim Şahin, Balkanlar'ın İslâmlaşması konusunda adından en fazla söz edilebilecek şahsiyetlerden birisi olan Sarı Saltuk'un hayatına dâir verilen bilgilerin menkıbe olmaktan öteye gidemediğini ve biyografisinden bahseden kaynakların birkaç yüzyıl sonra yazılmış olmalarının, şeyhin kimliği ve etkileri konusunda somut görüşler ileri sürülmesini zorlaştırdığını vurgulamış; ${ }^{74}$ Y. Averianov, Sarı Saltuk'un Türkmen gruplarla birlikte Balkanlara doğru ilerleyişi hususunda özellikle Yazıcızâde'de geçen kronolojik ve ayrıntılı bilgilerin müellif tarafından nasıl ve nereden elde edildiğini saptamanın mümkün olamayışına dikkat çekmiştir. ${ }^{75} \mathrm{~F}$. Temizyürek de imparatordan yakınlık gören II. Keykâvus'un kendilerine arazi tahsis edilmesi ve Anadolu'dan kendisine tâbi Türkmenleri getirtip bu arazide yaşamak istemesi üzerine imparatorun bu talepleri kabul ederek göç edenlerin Bulgaristan ve Romanya sınırları içerisinde kalan ve o dönemde iskâna açılmamış olan Dobruca'da yaşamasına müsâade ettiğini diğer araştırmalarla benzer şekilde belirtmiştir.76

Sarı Saltuk ve berâberinde Dobruca'ya göç edenlerin Oğuzların Çepni ${ }^{77}$ boyundan oldukları görüşü de hâkimdir. ${ }^{78}$ Babaîler isyanında etkin bir rol oynayan bu boy isyanın bastırılması ve Selçuklu kuvvetlerinin takibatı sebebiyle doğal olarak merkezden uzak mıntıkalara çekilmiştir. Nitekim Çepnilerin bir kısmının Sinop taraflarına yerleştiği bilinmektedir. Saltuknâme'nin pek çok yerinde Sarı Saltuk'un Sinop üzerinden Dobruca'ya gittiği hatta Sinop'tan Kırım'a Kırım'dan Sinop'a geçtiği vurgulanmakta bu durum Sinop'un Selçuklu hâkimiyetindeki liman kenti olmasının yanı sıra kentteki Çepni yerleşimiyle bağlantılı olabileceği de düşünülmektedir.79

Dobruca bölgesinin Karadeniz'in kuzeyinden gelerek Balkanlara inme emelinde olan devletlerin sâhip olmak istedikleri bir alan olduğu için tarihi seyri içinde pek çok kavim ve devlet tarafından kontrol altına alınmaya çalışıldığı da yapılan araştırmalarda vurgulanmıştır. Şöyle ki XII. ve XIII. yüzyıllarda bu bölgenin en önemli güçleri Bizans İmparatorluğu'nın yanı sıra Altın Orda ve Bulgar Devleti idi. Bu devletlerle ilişkileri bağlamında Peçenek ve Kuman gibi Türk devletleri de bölgenin kadim unsurlarıydılar. Bizans imparatoru bu sorunlu bölgeye yani

73 Necmettin Turinay, “Balkanlarda Türk Tarihi Açısından Özgün Bir Deneme: Sarı Saltuk, Bogomiller ve Bogomilizm”, Balkanlara Gidişinin 750. Yılında Uluslararası Sarı Saltuk Gazi Sempozyumu (6-10 Kasım 2013, KöstenceRomanya) Bildiriler, s. 214-215.

74 Haşim Şahin, “Arnavutluk Bektaşiliğinde Sarı Saltık Kültürü, I. Uluslararası Hacı Bektaş Veli Sempozyumu (0709 Mayıs 2010, Çorum) Bildiriler, Ankara 2011, I, s. 129-153;

75 Y. Averianov, “Личность Героя Сары Салтука И Суфийский Эпос”, ИРАН-НАЖ, Sayı: 2, (2012), s. 42.

76 Fahri Temizyürek, "Anadolu'dan Balkanlara Sarı Saltuk'un İzleri”, Balkanlara Gidişinin 750. Yılında Uluslararası Sarı Saltuk Gazi Sempozyumu (6-10 Kasım 2013, Köstence-Romanya) Bildiriler, Edirne 2014, s. 133.

77 Çepniler hakkında bkz. Faruk Sümer, Çepniler, İstanbul 1992; a. mlf., “Çepni”, DIA, VIII, 269-270.

78 A. Zeki Velidi Togan, Umumî Türk Tarihi'ne Giriş, C. I, İstanbul 1981, 268.

79 Ocak, a. g. e., s. 59; Kenan Ziya Taş, "Yeni Belgeler Işığında Sarı Saltuk'un Anadolu-Balkan Güzergâhında KuzeyBatı Anadolu'daki İzleri (16. Yüzyıl Arşiv Kayıtlarına Göre)", 2. Uluslararası Sarı Saltuk Gazi Sempozyumu (06-09 Mayıs 2015, Saraybosna-Bosna Hersek) Bildiriler, Edirne 2015, s. 122-123; S. Burhanettin Kapusuzoğlu-Mevlüt Çam, Balkanlar'da illk Müslüman Türk İskânının Öncüsü Sarı Saltık’n Makamları, İstanbul 2018. 
Dobruca ve çevresine Türkmenleri yerleştirerek kuvvetle muhtemel kuzeyden gelebilecek saldırılara karşı tampon bölge oluşturmak istemiştir. Dobruca bölgesinin fizikî koşulları ve iklimi de konar göçer Türkmenlerin yaşaması ve hayvancılık yapabilmeleri için elverişli olmuştur. ${ }^{80}$

\section{Sonuç}

Bu çalışmada kaynaklarda II. İzzeddin Keykâvus ve Sarı Saltuk arasındaki münâsebetlerle ilgili verilen mâlûmat ortaya konulmuş ve bilhassa yakın dönem müelliflerinin görüşlerine de yer verilerek Sultan II. İzzeddin Keykâvus'un gayretleriyle Dobruca yöresine gerçekleşen göçler hakkındaki görüşler ele alınmıştır. Devrin Bizans kaynaklarında bu yer değişimleri zikredilirken Sarı Saltuk'un rolü hakkında yeterince mâlûmatın bulunmadığı görülmüştür. Aynı durum doğrudan Selçuklu tarihin anlatan kaynaklarında da mevcuttur. En yakın tarihli kaynak olan İbnü's-Serrâc'ın vefatı 747 (1346) yılı civarıdır ve Osmanlı Devleti döneminde yazılmış kaynaklarda söz konusu hâdiselerin 622 (1263-1264) yılında gerçekleştiği zikredildiği için bu kaynağın da Sultan II. İzzeddin Keykâvus döneminde Dobruca'ya yaşanan göçlere doğrudan şâhit olması düşük bir ihtimâl görünmektedir. Her ne kadar Selçuknâmelerde yer verilmemiş olsa da Osmanlı tarih yazımında Sarı Saltuk ve berâberindeki Türkmenlerin göçleri, yerleşimleri ve gazâ faâliyetleri önemli bir yer teşkil etmektedir. Ancak burada da göze çarpan ufak tefek değişim ya da ilâvelerle Yazıcızâde'de geçen mâlûmata diğer eserlerde de yer verilmiş olması ve benzer bilgilerin bulunmasıdır. Bugüne kadar hakkında bu kadar çok araştırma yapılmış bir konuda yeni bir kaynağa tesadüf edilinceye kadar farklı şeyler söylemek pek de mümkün görünmemektedir.

Her ne kadar bu dönemde Türkmenlerin Dobruca'daki faâliyetleri hakkında yeterince bilgi mevcut olmasa bile Sarı Saltuk ve müritlerinin büyük kısmının II. İzzeddin Keykâvus'u Kırım'da da takip ettikleri ancak sultanın vefatından sonra yeniden Dobruca'ya döndükleri rivâyeti çalışmada başvurulan eserlerin çoğunda yer almaktadır. Bununla birlikte günümüzde yapılan araştırmalarda incelenen arkeolojik buluntular, türbeler, eski yerleşim merkezleri ve özellikle Sarı Saltuk hakkında dilden dile aktarılan menkıbeler, sözlü tarihler Sarı Saltuk liderliğindeki Türkmenlerin Balkanlarda nasıl kalıcı izler bıraktığını da göstermektedir.

\footnotetext{
Hakem Değerlendirmesi: Dış bağımsız.

Çıkar Çatışması: Yazar çıkar çatışması bildirmemiştir.

Finansal Destek: Yazar bu çalışma için finansal destek almadığını beyan etmiştir.

Peer-review: Externally peer-reviewed.

Conflict of Interest: The author has no conflict of interest to declare.

Grant Support: The author declared that this study has received no financial support.
}

80 Hacer Ateş, “Selçuklu'dan Osmanlı'ya İktidar Mücadelelerinde Sarı Saltuk Coğrafyası”, 2. Uluslararası Sarı Saltuk Gazi Sempozyumu (06-09 Mayıs 2015, Saraybosna-Bosna Hersek) Bildiriler, Edirne 2015, s. 96, 101. 


\section{Bibliyografya}

Akalın, Şükrü Halûk, “Ebü'l-Hayr-ı Rûmî’nin Saltuk-Nâme'si”, Türk Dili Araştırmaları Yıllığı Belleten, C. XL, (Ankara 1992), s. 37-59.

Akalın, Şükrü Halûk, Saltukname'ye Göre Sarı Saltuk", Balkanlara Gidişinin 750. Yılında Uluslararası Sarı Saltuk Gazi Sempozyumu (06-10 Kasım 2013, Köstence-Romanya) Bildiriler, Edirne 2014, s. 351-363.

Akalın, Şükrü Halûk, “Balkanlarda İslâm'ın ve Türklüğün Yayılmasında Bir Öncü: Sarı Saltuk”, ed. M. Savaş Kafkasyalı, Balkanlarda İslâm Miadı Dolmayan Umut, Ankara 2016, II, 51-71.

Akalın, Şükrü Halûk, “Ebülhayr Rûmî”, DiA, X, 360-362.

Aksarâyî, Kerîmüddin Mahmûd, Müsâmeretü'l-Ahbâr, Türkçe trc. Mürsel Öztürk, Ankara 2000.

Anetshofer, Helga, "Legends of Sarı Saltık in the Siyasetnâme and the Bektashi Oral Tradition", Evliyâ Çelebi Studies and Essays Commemorating the 400th Anniversary of his Birth, ed. Nuran Tezcan vd., İstanbul 2012, s. 296-304.

Ateş, Hacer, "Selçuklu'dan Osmanlı'ya İktidar Mücadelelerinde Sarı Saltuk Coğrafyası", 2. Uluslararası Sarı Saltuk Gazi Sempozyumu (06-09 Mayıs 2015, Saraybosna-Bosna Hersek) Bildiriler, Edirne 2015, s. 95-108.

Averianov, Y., “Личность Героя Сары Салтука И Суфийский Эпос", ИРАН-НАЖ, Sayı: 2, (2012), s. 38-62. Ayönü, Yusuf, Selçuklular ve Bizans, Ankara 2014.

Bal, Mehmet Suat, II. İzeddin Keykâvus Dönemi (1246-1262), Ankara Üniversitesi, Sosyal Bilimler Enstitüsü, Yayımlanmamış Doktora Tezi, Ankara 2004.

Bal, Mehmet Suat, “Türkiye Selçuklu Devleti Tarihinde Bir Dönüm Noktası; II. İzzeddin Keykavus Dönemi”, Tarih Araştırmaları Dergisi (TAD), C. XXIV, Sayı: 38, (2005), s. 239-258.

Bal, Mehmet Suat, “Türkiye Selçukluları, Mısır Memlükleri ve Altın Orda Devleti'nin İlhanlılara Karşı Kurduğu İttifak”, Selçuk Üniversitesi Türkiyat Araştırmaları Dergisi, Sayı: 17, (2005), s. 295-310.

Cahen, Claude, La Turquie pré-ottomane, Türkçe trc. Erol Üyepazarcı, Osmanlılardan Önce Anadolu, İstanbul 2000.

Decei, Aurel, "Le problème de la Colonisation des Turcs Seldjoucides dans la Dobroggea au XIII siècle", $T A D$, Sayı: 10, (1968), s. 85-111.

Demir, Necati, Sarı Saltık Gazi, İstanbul 2015.

Demir, Necati, “Saltuk-Nâme'nin Yeni Bulunan Altıncı Nüshası Üzerine”, Bilge, Sayı: 15, (Ankara 1998), s. 58-61.

Demir, Necati, “Tarihi, Kültürel ve Destani Bir Kaynak Olarak Saltıkname”, Balkanlara Gidişinin 750. Yılında Uluslararası Sarı Saltuk Gazi Sempozyumu (6-10 Kasım 2013, Köstence-Romanya) Bildiriler, Edirne 2014, s. 155-175.

Demir, Necati, "Saltık Gazi, Boşnaklar ve Bosna Hersek”, 2. Uluslararası Sarı Saltuk Gazi Sempozyumu (06-09 Mayıs 2015, Saraybosna-Bosna Hersek) Bildiriler, Edirne 2015, s. 177-200.

Demir, Necati-Turinay, Necmettin, Sarı Saltuk Bosna Hercegovina, Ankara 2017.

Deny, J., "Sari Saltiq et le nom de la ville de Babadaghi", Mélanges Offerts a M. Émile Picot, Paris 1913, II, s. 1-15.

Ebül-Fidâ, Takvîmü'l-Büldân, Türkçe trc. Ramazan Şeşen, Ebü'l-Fidâ Coğrafyası, İstanbul 2017.

Ebü'l-Hayr-ı Rûmî, Șaltuk-Nāme: The Legend of Sarı Șaltuk Collected from oral tradition by Ebü'l-Hayr Rūmī, nşr. Fahri İz-Şinasi Tekin, Gönül A. Tekin, Cambridge, Mass 1974-1984.

Ebü’l-Hayr-ı Rûmî, Saltuknâme, nşr. Şükrü Halûk Akalın, Ankara 1987-189, I-III. 
Ebü'l-Hayr-ı Rûmî, Saltıknâme (Saltık Gazi Destanı), nşr. Necati Demir-M. Dursun Erdem, İstanbul 2013, I-III.

Ekici, Kansu, Anadolu Selçuklu Devletinde Üç Kardeş Devri (1246-1266), Süleyman Demirel Üniversitesi Sosyal Bilimler Enstitüsü, Yayımlanmamış Yüksek Lisans Tezi, Isparta 2005.

Evliya Çelebi, Günümüz Türkçesiyle Evliyâ Çelebi Seyahatnâmesi: Akkirman-Belgrad-Gelibolu-ManastırÖzü-Saraybosna-Slovenya-Tokat-Üsküp, haz. Seyit Ali Kahraman, 5. Cilt 1. Kısım, İstanbul 2010.

Gregoras, Nikephoros, Corpus Scriprorum Historiae Byzantinae, ed. L. Schpon, Bonnae 1829.

Guboglo, M. N., “Gagauzların Etnik Aidiyeti”, Türkçe trc. Bülent Hünerli, TÜRÜK Uluslararası Dil, Edebiyat ve Halkbilimi Araştırmaları Dergisi, 2018, Yıl: 6, Sayı: 12, s. 67-78.

Güngör, H.-Argunşah, M., Gagauz Türkleri, Tarih-Dil-Folklor ve Halk Edebiyatı, Ankara 1991.

Hammer, J. Von, Histoire de L'Empire Ottoman: Depuis Son Origine Jusqu'à nos Jours, Paris 1840, I, IV. Hünerli, Bülent, Mihail Çakir'in Gagauzca (Türkçe)-Rumence Sözlüğü (Inceleme-Metin), Çanakkale 2019. Hünerli, Bülent, "Gagauzlar ve Lozan Mübadelesinin Pek Bilinmeyen Bir Yönü: Yunanistan Gagauzları", Mübadil Kentler: Türkçe Konuşan Rum Ortodokslar, ed. Yonca Cingöz, İstanbul 2019, s. 87-100.

İbn Battûta, Ibn Battûta Seyahatnâmesi, Türkçe trc. A. Sait Aykut, İstanbul 2004, I.

İbn Bîbî, el-Evâmirül- 'Alấ'iyye fi'l-umûri'l- 'Alâ'iyye, Türkçe trc. Mürsel Öztürk, Ankara 1996, II.

İbnü'l-ïbrî, Abû'l-Farac Tarihi, Türkçe trc. Ömer Rıza Doğrul, Ankara 1950, II.

İbnü'l-ibrî, Târîhu muhtasari'd-düvel, Beyrut 1308/1890.

İbnü's-Serrâc, Tuffâhu'l-Ervâh ve Miftâhu'l-Irbâh, Ruhların Meyvesi ve Kazancın Anahtarı, Türkçe trc. Nejdet Gürkan-Mehmet Necmettin Bardakçı-Mehmet Saffet Sarıkaya, İstanbul 2015.

Kapusuzoğlu, S. Burhanettin-Çam, Mevlüt, Balkanlar'da Illk Müslüman Türk İskânının Öncüsü Sarı Saltık'ın Makamları, İstanbul 2018.

Karamustafa, Ahmet, T., “Islamisation through the Lens of the Saltuk-name", Islam and Christianity in Medieval Anatolia, ed. A. C. S. Peacock, Bruno de Nicola, Sara Nur Yıldız, Farnham 2015, s. 349-364.

Karpat, Kemal, “Gagauzlar”, DIA, XIII, 288-291.

Kemalpaşazâde, Histoire de Campagne de Mohacz, nşr. Pavet de Courteielle, Paris 1859.

Kiel, Michael, "Sarı Saltık ve Erken Bektaşilik Üzerine Notlar", Türkçe trc. Fikret Elpe, Türk Dünyası Araştırmaları Dergisi, C. II, Sayı: 9, 1980, s. 25-36.

Kiel, Michael, “Sarı Saltuk”, DIA, XXXVI, 147-150.

Korobeinikov, Dimitri, Byzantium and The Turks in the Thirteenth Century, Oxford 2014.

Köprülü, M. Fuad, Türk Edebiyatında Illk Mutasavvıflar, Ankara 1976.

Köprülü, M. Fuad, “Anadolu Selçukluları Tarihi'nin Yerli Kaynakları I”, Belleten, C. VII, Sayı: 27, Ankara, 1943, s. 379-525.

Lokmân b. Hüseyin, Seid Locmani ex Libro Turcico qui Oghuznāme inscribitur excerpta, nşr. J. J. Wilhelm Lagus, Helsiogforsiae 1854.

Matanov, Hristo, “Селджукски турци в Добруджа през XIII век?”, Списание Път, Sayı: 13, (2010), s. 14-21.

Mélikoff, I., "Qui était Sarı Saltuk? Quelques Remarques sur les Manuscrits du Saltukname”, Studies in Ottoman History in Honour of Prof. V. L. Mélange, ed. C. Heyvood-C. Imber, İstanbul 1994, s. 231-238.

Merçil, Erdoğan, “Bizans'ta Selçuklu Hanedan Mensupları”, XI. Türk Tarih Kongresi (5-9 Eylül 1990, Ankara) Bildiriler, Ankara 1994, II, s. 709-721.

Murgescu, Bogdan, “ísakça”, DiA, XXII, 489-490. 
Müneccimbaşı Ahmed b. Lütfullah, Câmiu'd-Düvel, yay. ve Türkçe trc. Ali Öngül, Câmiu'd-Düvel Selçuklular Tarihi II, Anadolu Selçukluları ve Beylikleri, İstanbul 2017.

Ocak, Ahmet Yaşar, Sarı Saltık Popüler İslâm’ın Balkanlar'daki DestanîÖncüsü (XIII. Yüzyıl), Ankara 2011.

Ocak, Ahmet Yaşar, “Barak Baba”, DiA, V, 61-62.

Okiç, Tayyib, "Sarı Saltuk'a Ait Bir Fetva”, Ankara Üniversitesi Ilahiyat Fakültesi Dergisi (AÜiFD), C. I, Sayı: 1, (1952), s. 48-58.

Ostrogorsky, Georg, Bizans Devleti Tarihi, Türkçe trc. Fikret Işıltan, Ankara 2011.

Öden, Zerrin Günal, “Türkiye Selçuklu Sultanı II. Gıyaseddin Mesud Hakkında Bazı Görüşler”, Belleten, C. LXI, Sayı: 231'den ayribasım, Ankara 1997, s. 287-300.

Özaydın, Abdülkerim, “Anadolu Selçukluları”, Siyasî-Dinî-Kültürel-Sosyal İslâm Tarihi, İstanbul 1994, VIII, 86-241.

Pachymeres, Georgios, Georges Pachymérès Relations Historiques, ed. Albert Failler, Paris 1984-1999, I-III. Pachymeres, Georgios, Bizanslı Gözüyle Türkler, Türkçe trc. İlcan Bihter Barlas, İstanbul 2009.

Rahimova, Aybeniz, “Oğuzların Dini Kahramanlık Destanı Saltukname”, Türk Dünyası Araştırmaları (TDA), C. 123, Sayı: 243, (Kasım-Aralık 2019), s. 249-25.

Rice, Tamara Talbot, The Seljuks in Asia Minor, London 1961.

Shukurov, Rustam, The Byzantine Turks 1204-1461, Leiden 2016.

Shukurov, Rustam, "The Oriental Margins of the Byzantine World: A Prosopographical Perspective", Identities and Allegiances in the Eastern Mediterranean after 1204, ed. Judith Herrin-Guillaume Saint-Guillain, Aldershot 2011, s. 167-196.

Sümer, Faruk, Çepniler, İstanbul 1992.

Sümer, Faruk, “Çepni”, DIA, VIII, 269-270.

Sümer, Faruk, “Keykâvus II”, DiA, XXV, 355-357.

Sümer, Faruk, "Selçuklular III. Anadolu Selçukluları (1075-1038)", Türkiye Diyanet Vakfı İslâm Ansiklopedisi (DIA), XXXVI, 380-384.

Şahin, Haşim, "Arnavutluk Bektaşiliğinde Sarı Saltık Kültürü, I. Uluslararası Hacı Bektaş Veli Sempozyumu (07-09 Mayıs 2010, Çorum) Bildiriler, Ankara 2011, I, s. 129-153.

Şeker, Mehmet, “Anadolu'nun Türk Vatanı Haline Gelmesi”, Türkler, Ankara 2002, C. VI, 269-282.

Târih-i Âl-i Selçuk (Anonim Selçuknâme), Türkçe trc. Halil İbrahim Gök-Fahrettin Coşguner, Ankara 2014.

Taş, Kenan Ziya, “Yeni Belgeler Işığında Sarı Saltuk'un Anadolu-Balkan Güzergâhında Kuzey-Batı Anadolu'daki İzleri (16. Yüzyıl Arşiv Kayıtlarına Göre)", 2. Uluslararası Sarı Saltuk Gazi Sempozyumu (06-09 Mayıs 2015, Saraybosna-Bosna Hersek) Bildiriler, Edirne 2015, s. 109-124.

Taşdelen, H. Musa, Bulgaristan, Romanya ve Kırım Müslüman Topluluklarda Sarı Saltık Algısı "Referans Kişilik Olarak Bir Kolonizatör Türk Dervişi", İstanbul 2015.

Temizyürek, Fahri, “Anadolu'dan Balkanlara Sarı Saltuk'un İzleri”, Balkanlara Gidişinin 750. Yılında Uluslararası Sarı Saltuk Gazi Sempozyumu (6-10 Kasım 2013, Köstence-Romanya) Bildiriler, Edirne 2014, s. 131-138.

Tevhid, Ahmed, “Rum Selçûkî Devleti'nin İnııâzıyla Teşekkül Eden Tavâif-i Mülûk'den Karahisar-ı Sâhib'de Sâhibataoğulları", Târîh-i Osmânî Encümeni Mecmuası (TOEM), II, Sayı: 9, İstanbul 1329, s. 563-568.

Togan, A. Zeki Velidi, Umumî Türk Tarihi'ne Giriş, C. I, İstanbul 1981.

Turan, Osman, Selçuklular Zamanında Türkiye, İstanbul 1971. 
Turinay, Necmettin, "Balkanlarda Türk Tarihi Açısından Özgün Bir Deneme: Sarı Saltuk, Bogomiller ve Bogomilizm", Balkanlara Gidişinin 750. Yılında Uluslararası Sarı Saltuk Gazi Sempozyumu (6-10 Kasım 2013, Köstence-Romanya) Bildiriler, Edirne 2014, s. 177-216.

Turinay, Necmettin, "Saltıkname'nin Meçhul Yazıcısı: Ebulhayr-ı Rumî”, 2. Uluslararası Sarı Saltuk Gazi Sempozyumu (06-09 Mayıs 2015, Saraybosna-Bosna Hersek) Bildiriler, Edirne 2015, s. 201-220.

Vásáry, István, Cumans and Tatars Oriental Military in the Pre-Ottoman Balkans, 1185-1365, Cambridge 2005.

Wittek, Paul, "Yazijioghlu 'Alī on the Christian Turks of the Dobruja", Bulletin of the School of Oriental and African Studies (BSOAS), XIV/3, (1952), 639-668.

Yazıcızâde Ali, Tevârîh-i Âl-i Selçuk, (Selçuklu Tarihi), nşr. Abdullah Bakır, İstanbul 2009.

Yuvalı, Abdülkadir, "ilhanlılar", DIA, XXII, 102-105.

Yüce, Kemal, Saltuk-nâme'de Tarihî, Dinî ve Efsanevî Unsurlar, Ankara 1987.

Zayonçkovskiy, Vlodzimej, “Gagauzların Etnogenezine Dair”, Türkçe trc. Bülent Hünerli, TÜRÜK Uluslararası Dil, Edebiyat ve Halkbilimi Araştırmaları Dergisi, 2018, Yıl: 6, Sayı: 14, s. 247-253. 
